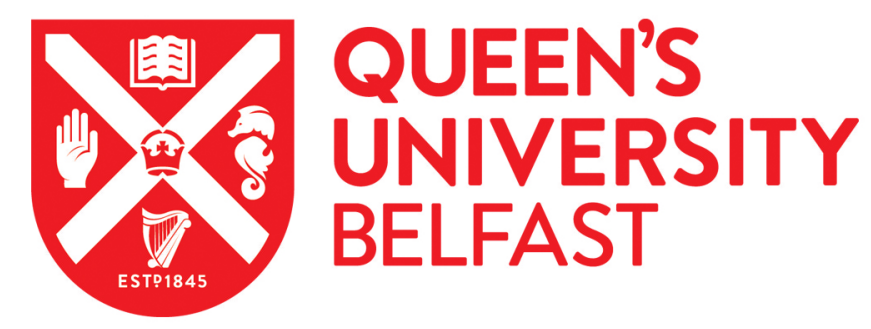

\title{
The Development of the UNIFAC-CONDUCT Model as a Novel Approach for the Estimation of the Conductivity of Pure lonic Liquids
}

Zhao, N., \& Jacquemin, J. (2017). The Development of the UNIFAC-CONDUCT Model as a Novel Approach for the Estimation of the Conductivity of Pure Ionic Liquids. Fluid Phase Equilibria.

https://doi.org/10.1016/j.fluid.2017.06.010

\section{Published in:}

Fluid Phase Equilibria

\section{Document Version:}

Peer reviewed version

\section{Queen's University Belfast - Research Portal:}

Link to publication record in Queen's University Belfast Research Portal

\section{Publisher rights}

Copyright 2017 Elsevier.

This manuscript is distributed under a Creative Commons Attribution-NonCommercial-NoDerivs License

(https://creativecommons.org/licenses/by-nc-nd/4.0/), which permits distribution and reproduction for non-commercial purposes, provided the author and source are cited.

\section{General rights}

Copyright for the publications made accessible via the Queen's University Belfast Research Portal is retained by the author(s) and / or other copyright owners and it is a condition of accessing these publications that users recognise and abide by the legal requirements associated with these rights.

Take down policy

The Research Portal is Queen's institutional repository that provides access to Queen's research output. Every effort has been made to ensure that content in the Research Portal does not infringe any person's rights, or applicable UK laws. If you discover content in the Research Portal that you believe breaches copyright or violates any law, please contact openaccess@qub.ac.uk. 
The Development of the UNIFAC-CONDUCT Model as a Novel Approach for the Estimation of the Conductivity of Pure lonic Liquids

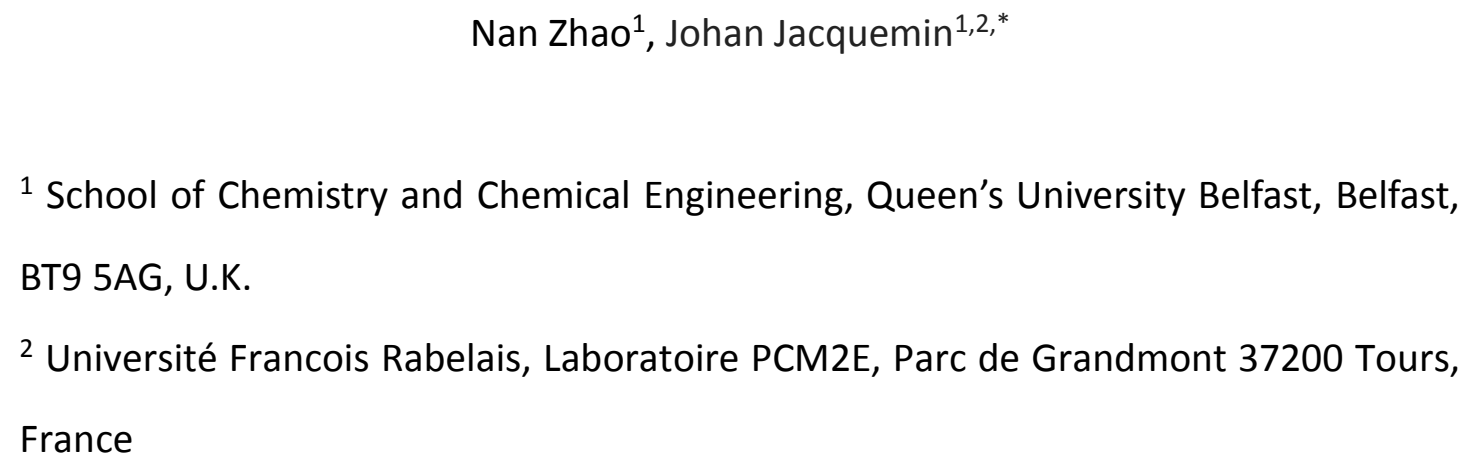

${ }^{1}$ School of Chemistry and Chemical Engineering, Queen's University Belfast, Belfast, BT9 5AG, U.K.

2 Université Francois Rabelais, Laboratoire PCM2E, Parc de Grandmont 37200 Tours, France

Corresponding Author: Johan Jacquemin, E-mail: johan.jacquemin@qub.ac.uk or ij@univ-tours.fr 


\section{Abstract}

The correlation and prediction of physical properties of ionic liquids (ILs) is important in the development and design of novel structures for a variety of applications. In particular, for the application as electrolytic media for electrochemical applications, the electrical conductivity of ILs is an important property. Herein, we define a novel model called the UNIFAC-CONDUCT for the estimation of IL conductivity which mimics the principles of the UNIFAC-VISCO model. 784 data points for 38 ILs were used to establish this group contribution model, covering a wide range of temperature (248.15-468.15 K) and a broad range of electrical conductivity $\left(0.002-14.54 \mathrm{~S} \cdot \mathrm{m}^{-1}\right)$. Three sets of UNIFAC-CONDUCT parameters were determined to calculate the conductivity of pure ILs by three methodologies wherein the parameters of ion VFT equations, $A, B$ and $T_{o}$, and binary interaction parameters, $\alpha_{m n}$, are selectively either fixed (based on previously reported values) and/or optimized by Marquardt technique. Correlations by the three methods are compared and analyzed, and further correlated with the previously predicted viscosities using the Nernst-Stokes relationship to support the quality of both the UNIFAC-VISCO model, previously proposed by our group, and the UNIFAC-CONDUCT model developed in this paper. Finally, the quality of the proposed method was further assessed through the prediction of the conductivity of one binary system containing two different ILS as the function of the temperature and composition with an accuracy close to $4.1 \%$.

Keywords: Ionic Liquids; Conductivity; Temperature; UNIFAC-CONDUCT; Group Contribution Model 


\section{Introduction}

Ionic liquids (ILS) are organic salts that are liquid at temperature below $100{ }^{\circ} \mathrm{C}$ [1]. Recently, ILs have been investigated increasingly in industry and academia, due to their low vapor pressure, high conductivity, wide electrochemical window, and chemical and thermal stability. It is well-recognized that one of the most promising application for ILs is their use as electrolytes for energy storage systems, such as batteries, fuel cells and supercapacitors [2]. For these applications, the design of task-specific ILs with high ionic conductivity is crucial. Hence, a thorough knowledge of their conductivities is essential to formulate novel electrolytes [3]. Taking into account the number of possible IL combinations, the development of methods able to estimate accurately their properties is highly desired.

Literature models have been reported for the prediction and correlation of ionic conductivity of pure ILs. The first approach is to relate the conductivity to other properties of ILs. Slattery et al. [4] reported a strong relationship between the molecular volumes, $V_{m}$, and conductivities, $\sigma$, of ILs, as shown in eq. 1.

$\ln \sigma=-d V_{m}+\operatorname{lnh}$

where $d$ and $h$ are fitting parameters.

Using this relationship, these authors correlated the experimental conductivities of $\left[\mathrm{NTf}_{2}\right]^{-},[\mathrm{DCA}]^{-},\left[\mathrm{BF}_{4}\right]^{-}$, and $\left[\mathrm{PF}_{6}\right]^{-}$based ILs using eq. 1 with $R^{2}$ being 0.9871 [4]. However, in this instance, limited data points were used; only $12,3,3$, and 3 data points for $\left[\mathrm{NTf}_{2}\right]^{-},[\mathrm{DCA}]^{-},\left[\mathrm{BF}_{4}\right]^{-}$, and $\left[\mathrm{PF}_{6}\right]^{-}$based ILs, respectively.

In addition, Bogdanov et al. [5] proposed another linear correlation (eq. 2) between 
the conductivity of $X$-substituted ILs and substituent constant, $\beta^{X}$, for each homologous series of ILs. In total 69 experimental data points, covering 17 homologous series of ILs, were selected, with the fitting result $\left(R^{2}\right)$ better than 0.9615 .

$\ln \sigma=a \beta^{X}+\ln \sigma^{0}$

where, $a$ and $\sigma^{0}$ are a fitting parameter and the conductivity of the methyl-substituted IL of a homologous series, respectively.

The second approach is the group contribution model for the prediction of the electrical conductivity of ILs. Gardas and Coutinho [6] calculated the adjustable parameters $(A$ and $B$ ) of the Vogel-Fulcher-Tammann (VFT) equation (eq. 3) by using a group contribution method (eqs. 4-5) by fixing the fitting parameter related to the temperature, $T_{0}$, to $165.06 \mathrm{~K}$ for all ILs studied.

$\ln \sigma=\ln A+\frac{B}{T-T_{0}}$

$A=\sum_{i=1}^{N} n_{i} a_{i}$

$B=\sum_{i=1}^{N} n_{i} b_{i}$

where $N$ is the total number of different groups in the IL, $n_{i}$ is the number of occurrences of group $i$, and $a_{i}$ and $b_{i}$ are parameters of group $i$. In total 307 experimental data points from 15 ILs were regressed to obtain the group parameters $a_{i}$ and $b_{i}$, with a $4.57 \%$ overall relative deviation between the experimental data and the correlated values.

Similar to the method proposed by Gardas and Coutinho [6], and Wu et al. [3] expressed the adjustable parameters $\left(A, B\right.$, and $\left.T_{0}\right)$ of the VFT equation using a 
series of more complicated group contribution equations (eqs. 6-8).

$A=A_{0}+\sum_{m=1}^{2} \sum_{i=1}^{N} n_{i}^{m}\left(W A_{m, i}\right)$

$B=\left(B_{0}+\sum_{m=1}^{2} \sum_{i=1}^{N} n_{i}^{m}\left(W B_{m, i}\right)\left(B_{0}^{\prime}+\sum_{m=1}^{2} \sum_{i=1}^{N} n_{i}^{m}\left(W B_{m, i}^{\prime}\right)\right)\right.$

$T_{0}=T_{0}^{\prime}+\sum_{m=1}^{2} \sum_{i=1}^{N} n_{i}^{m}\left(W T_{0 m, i}\right)$

where $W A_{m, i}, W T_{0 m, i}, W B_{m, i}$ and $W B_{m, i}^{\prime}$ are contributions of the $m_{\text {th-order }}$ group $i, A_{0}, T_{0}, B_{0}$, and $B_{0}^{\prime}$ are values of all computed coefficients. Herein, the observed deviations between the experimental and evaluated results for training (1978 data points of 177 ILs) and testing (217 data points of 11 ILs) were $6.12 \%$ and $5.10 \%$, respectively.

Gharagheizi et al. [7] proposed a least square support vector machine-group contribution (LSSVM-GC) model for the estimation of pure conductivity. Parameters $\sigma_{c i}(i=1,2, \ldots 11)$ of 11 sub-structures on cations and parameters $\sigma_{a i}(i=1,2, \ldots 11)$ of 11 sub-structures on anions were used to establish this group contribution model. An average deviation of $3.3 \%$ is acceptable given that 1077 experimental conductivities for 54 ILs were predicted. However, the complexity of this model limits its applicability to a wider range of types of ILs.

The fourth approach reported in the literature is based on the hole theory. Abbott [8] first applied the hole theory to predict the viscosity of ILs. Afterwards, Zhao et al. [9] modified the hole theory model to facilitate the estimation of the conductivity of ILS and reported a comparison of the new and conventional hole models by utilizing a range of 24 ILs (one data point for each IL). They report that the estimation accuracy of the new methodology was increased from the order of $27 \%$, by the original 
method, to $11.87 \%$.

Tochigi et al. [10,11] proposed two different Quantitative Structure Property Relationship methods (QSPR) for the estimation of conductivity of ILs. Two different sets of descriptors, establishing two different polynomial expansion models, were used to calculate the conductivity of ILs. However, it is not convenient to apply these methods due to the complexity of the polynomial expansions.

In this work, we define a novel model called the UNIFAC-CODUCT, on the basis of the UNIFAC model, for the estimation of the conductivity of pure ILs. 784 experimental conductivities of 38 ILs were collected from the NIST database [12], covering a wide range of temperature $(248.15-468.15 \mathrm{~K})$ and electrical conductivity $(0.002-14.54$ $\mathrm{S} \cdot \mathrm{m}^{-1}$ ) to establish the UNIFAC-CONDUCT model as reported in Table 1 [13-39]. According to the NIST database, the uncertainty of the conductivity datasets reported in the literature is within $\pm 3 \%[12]$. 


\section{Methodology}

\subsection{The UNIFAC-CONDUCT model.}

In our previous paper $[40,41]$, new methods based on the UNIFAC-VISCO model have been reported for the evaluation of the viscosity of pure ILs, and their mixtures with another IL or molecular solvent, (IL + IL) or (IL + solvent) binary mixtures as the function of temperature and composition at atmospheric pressure. It is very well-known that the conductivity is a nonlinear property and, like viscosity, can be fitted by using the simple exponential equations, such as Arrhenius, Litovitz, and VFT equations [42]. Consequently, the UNIFAC-based model, namely the UNIFAC-CONDUCT, was developed herein to estimate the conductivity of pure ILS. The equations of the UNIFAC-CONDUCT model, described below, are similar to the UNIFAC-VISCO formulations described by our group previously [40].

The conductivity in the UNIFAC-CONDUCT method is defined as:

$\ln \sigma=\sum_{i=1}^{C} x_{i} \ln \left(\sigma_{i} \cdot \frac{V_{i}}{V_{m}}\right)+\frac{g_{c}^{E}}{R T}-\frac{g_{r}^{E}}{R T}$

Herein, subscript $i$ represents the component $i$ in the pure IL (i.e., the cation and anion); $C$ is the number of the components in the IL and equal to $2 ; x_{i}$ is the mole fraction of the cation/anion $\left(x_{1}=x_{2}=0.5\right) ; \sigma_{i}$ is the conductivity of the ion and expressed by using the VFT equation (eq. 10); $V_{i}$ is the effective molar volume of the ion and calculated based on a group contribution method previously proposed by our group [43,44]; $V_{m}$ is the molar volume of the pure IL;

$$
\begin{aligned}
& \sigma_{i}=A \cdot \exp \left[\frac{-B}{T-T_{0}}\right] \\
& V_{i}\left(\delta T, p_{\text {ref }}\right)=\sum_{i=0}^{2}\left(D_{i} \cdot(\delta T)_{p_{r e f}}^{i}\right)
\end{aligned}
$$


where $\delta T=T-298.15, p_{\text {ref }}=0.1 \mathrm{MPa}$, and $D_{i}$ is the volumetric parameters at reference pressure. The values of the volumetric parameters used during this work are presented in Table S1 of the Supporting Information.

The UNIFAC-CONDUCT combinatorial term reported in the eq. 9 is defined by:

$\frac{g_{c}^{E}}{R T}=\sum_{i=1}^{C} x_{i} \ln \frac{\phi_{i}}{x_{i}}+5 \sum_{i=1}^{C} x_{i} q_{i} \ln \frac{\theta_{i}}{\phi_{i}}$

where

$\theta_{i}=\frac{x_{i} q_{i}}{\sum_{j} x_{j} q_{j}}$

$\phi_{i}=\frac{x_{i} r_{i}}{\sum_{j} x_{j} r_{j}}$

$q_{i}=\sum_{k=1}^{N} n_{i, k} Q_{k}$

$r_{i}=\sum_{k=1}^{N} n_{i, k} R_{k}$

where subscript $k$ denotes the groups; $N$ is the total number of groups present; $n_{i, k}$ is the total number of $k_{t h}$ group present in component $i ; Q_{k}$ and $R_{k}$ are the group surface area parameter and volume parameter, respectively. The values of volume $R$ and surface area $Q$ parameters of ions used were simulated by using the COSMOtherm software (version C30_1501) by following the methodology previously described by our group [45], and are given in the Table S2 of the Supporting Information.

The UNIFAC-CONDUCT residual term reported in the eq. 9 is defined by:

$\frac{g_{r}^{E}}{R T}=\sum_{i=1}^{C} x_{i}\left[\sum_{m=1}^{N} n_{m, i}\left(\ln \gamma_{m}-\ln \gamma_{m, i}\right)\right]$

where $\ln \gamma_{m}$ is the residual activity coefficient and can be calculated as follows:

$\ln \gamma_{m}=Q_{m}\left[1-\ln \left(\sum_{i=1}^{N} \Theta_{i} \Psi_{i, m}\right)-\sum_{i=1}^{N} \frac{\Theta_{i} \Psi_{m, i}}{\sum_{j=1}^{N} \Theta_{j} \Psi_{j, i}}\right]$

where 
$\Theta_{m}=\frac{X_{m} Q_{m}}{\sum_{i=1}^{N} X_{i} Q_{i}}, \quad m=1,2,3, \ldots, N$

$\Psi_{m n}=\exp \left(-\frac{\alpha_{m n}}{298.15}\right)$

where $\alpha_{m n}$ are the group interaction potential energy parameters between $m$ and $n$, determined through the regression of the collected experimental data as reported in the Supporting Information. Herein, the COSMOthermX software was used to determine only the group surface area $\left(Q_{k}\right)$ and volume $\left(R_{k}\right)$ parameters, which are required for the calculation of the UNIFAC-CONDUCT combinatorial term.

In our previous work, a set of binary interaction parameters $\alpha_{m n}$ between ionic groups and a set of VFT parameters $\left(A, B\right.$, and $\left.T_{0}\right)$ for the effective viscosity of ions have been reported [41]. Herein, three methods were applied for the estimation of pure ILs conductivity and the results determined by these three methods are compared and analyzed. To obtain the unknown parameters, we performed the Marquardt optimization [46] of the objective function (OF), as reported in eq. 21.

$O F=\frac{1}{M} \sum_{i=1}^{M}\left(\frac{\sigma_{\text {exp }}-\sigma_{\text {cal }}}{\sigma_{\text {exp }}}\right)^{2} \rightarrow \min$

Herein, 784 experimental conductivity data of 38 ILs were regressed altogether and this regression process was achieved by using a nonlinear least-squares function in MATLAB Optimization Toolbox. An overview of the experimental data collected for 38 ILs is presented in Table 1. The developed MATLAB program, available in the supporting information, contains all parameters (binary interaction and VFT 
parameters) estimated during this study for each method reported below.

2.2 Method 1: Estimation of IL conductivity by using a fixed set of $\alpha_{m n}$ and $T_{0}$. The first method is to fix the values of interaction parameters $\alpha_{m n}$ and the values of reference temperature $T_{0}$ for each ion as those described in our previous work for the UNIFAC-VISCO model [41]. In this case, the unknown parameters are only $A$ and $B$ of the VFT equations, used to describe the effective conductivity of ions as a function of temperature.

\subsection{Method 2: Estimation of IL conductivity by using a fixed set of $\alpha_{m n}$.}

For the second method, we only keep the values of $\alpha_{m n}$ as reported in our previous work [41], and the ion VFT parameters $\left(A, B\right.$, and $\left.T_{0}\right)$ were calculated by minimization of the objective function using all the experimental data.

\subsection{Method 3: Estimation of IL conductivity by using a new set of $\alpha_{m n}$ and $T_{0}$.}

The third method is to obtain a totally new set of parameters $\left(\alpha_{m n}\right.$ and $\left.T_{0}\right)$ which could be potentially used only for the UNIFAC-CONDUCT model by minimization of the objective function using all the experimental data. 


\section{Results and Discussion}

Three sets of UNIFAC-CONDUCT parameters (i.e. VFT parameters and binary interaction parameters $\alpha_{m n}$ ) are listed in Tables S3-S7 of the Supporting Information. The regression results were demonstrated by calculating the relative absolute average deviation (RAAD, eq. 22 ) between the experimental conductivities and the correlated values.

$R A A D=100 \times \frac{1}{M} \sum_{i=0}^{M}\left|\frac{\sigma_{e x p}-\sigma_{c a l}}{\sigma_{\text {exp }}}\right|$

The overall RAAD resulting from the first, second, and the third method is close to $9.9 \%, 9.2 \%$, and $2.3 \%$, respectively. The parity plots between the experimental and the calculated values by using these three different methods are shown in Figure 1. Comparing both plots (a) and (b) reported in Figure 1 and data reported in the database spreadsheet available in the Supporting Information, it can be noticed that the values of the parameter $T_{0}$ in the VFT equations of ions have a small influence on the performance of the evaluation of the pure ILs conductivity. However, the comparison of both plots (b) and (c) from Figure 1 clearly shows that the global optimized values of $\alpha_{m n}$ can significantly increase the accuracy of the UNIFAC-CONDUCT model during the estimation of the pure ILs conductivity. This is further exemplified in Figures 2-4 where the effect of temperature, cations and anions structure on the quality of each correlation is reported. As illustrated in Figure 2 in the case of the [ $\left.\mathrm{C}_{4} \mathrm{mpyrro}\right]\left[\mathrm{NTf}_{2}\right]$ using the dataset published by Vranes et al. [34], each method is able to correlate the temperature dependence on the IL conductivity. Similarly, as shown in Figures 3 and 4, effects of both anion and cation structure on 
the conductivity seem to be properly described by each method. From Figure 4, one can clearly see, as expected from literature data $[16,29,30,33,34,36]$, an increase of the alkyl chain length from $n=1$ to 2 for the series [ $C_{n}$ mim] $\left[N T f_{2}\right]$ results in a slight increase in conductivity prior to a marked decrease (for $n>2$ ), for example. However, it can be also notified from Figure 4 that at $298.15 \mathrm{~K}$, by using both methods 1 and 2 the conductivity data are over or under predicted for short $(n<4)$ or for long $(n>4)$ alkyl chain length, which is not observed in the case of the method 3 as expected. However, the original idea to keep the values of the $T_{0}$ and $\alpha_{m n}$ parameters in the UNIFAC-CONDUCT model similar to those determined for the UNIFAC-VISCO model [41] has a physical meaning, which may reflect the ILs cohesive energy. Furthermore, this logic also limits the number of unknown parameters during the regression and thus the estimation of the conductivity and/or viscosity of pure ILs.

To further assess this approach, viscosity and conductivity data for the [ $\left.\mathrm{C}_{6} \mathrm{mim}\right][\mathrm{eFAP}]$ and $\left[\mathrm{C}_{4}\right.$ mpyrro][NTf $\left.{ }_{2}\right]$ were evaluated by using the UNIFAC-VISCO and UNIFAC-CONDUCT models prior to verifying their relationship in terms of the Nernst-Einstein and Stokes-Einstein equations. These two ILs have been selected to represent more hydrolytically and electrochemically stable ILs compared to the conventional $\left[\mathrm{BF}_{4}\right]^{-}$and $\left[\mathrm{PF}_{6}\right]^{-}$ILs typically used which are hydrolytically unstable $[1,36]$. In particular, the $\left[\mathrm{C}_{4} \mathrm{mpyrro}\right]\left[\mathrm{NTf}_{2}\right]$ is commonly used by several research groups to formulate electrolytes for energy storage systems [2].

According to the Nernst-Einstein equation, the molar conductivity $(\Lambda)$ of an electrolyte species is related to its self-diffusion coefficient $(D)$ as follows: 
$\Lambda=\frac{z^{2} N_{A} e_{0}^{2} D}{k_{B} T}$

where $z$ is the valence of the charge carrier, $N_{A}$ is the Avogadro number, $e_{0}$ is the elementary charge, and $k_{B}$ is the Boltzmann constant. The molar conductivity $(\Lambda)$ is defined as the conductivity $(\sigma)$ divided by the concentration of the charge carriers $(c):$

$\Lambda=\frac{\sigma}{c}=\frac{\sigma}{n / V}=\frac{\sigma}{\left(N / N_{A}\right) / V}$

where, $n$ is the moles of the charge carriers, $N_{A}$ is the Avogadro number, and $N$ is the number of charge carriers in the volume $V$.

Furthermore, the self-diffusion coefficient $D$ is defined by the Stokes-Einstein equation as follows:

$D=\frac{k_{B} T}{6 \pi r \eta}$

where, $r$ is the effective radius and $\eta$ is the viscosity of the charge carriers.

Consequently, the relationship between the conductivity $(\sigma)$ and viscosity $(\eta)$ is derived by combining the Eqs. 23-25:

$\sigma=\frac{z^{2} e_{0}^{2} N}{6 V \pi r \eta}=k \cdot \frac{1}{\eta}$

where, $k$ is the slope.

According to eq. 26, it can be observed that the conductivity is inversely proportional to the viscosity. Figure 5 shows the calculated conductivity of the selected ionic liquids by the UNIFAC-CONDUCT model as a function of the inverse viscosity calculated by the UNIFAC-VISCO model [41], using identical values of a set of parameters $\alpha_{m n}$ and $T_{0}$ (first method). As shown in Figure 5, an excellent linear fitting between the inverse calculated viscosity and the calculated conductivity is 
observed, which also proves the evaluation capability of the UNIFAC-VISCO model previously developed by our group $[40,41]$ and the UNIFAC-CONDUCT model proposed during this work.

To further assess this approach, the conductivity of the $\left(\left[\mathrm{C}_{2} \mathrm{mim}\right][\mathrm{DCA}]+\right.$ $\left.\left[\mathrm{C}_{2} \mathrm{mim}\right][\mathrm{SCN}]\right)$ binary system was purely predicted using the UNIFAC-CONDUCT model with the $\alpha_{m n}$ parameters, reported previously, from the UNIFAC-VISCO model [41]. The literature experimental dataset used during this assessment is also reported in Table 2 [47]. As shown in Figure 6, an excellent agreement was observed between the experimental and the predicted conductivity data of the $\left(\left[\mathrm{C}_{2} \mathrm{mim}\right][\mathrm{DCA}]\right.$ $\left.+\left[\mathrm{C}_{2} \mathrm{mim}\right][\mathrm{SCN}]\right)$ binary system with an overall relative absolute average deviation close to $4.1 \%$. This result is very promising considering, firstly, the approach used, i.e. using reported parameters for the UNIFAC-VISCO, and secondly, the possibility to determine the conductivity of this mixture as a function of both composition and temperature. 


\section{Conclusion}

During this work, a novel model called the UNIFAC-CONDUCT, which mimics the UNIFAC-VISCO model, is defined for the estimation of the electrical conductivity of pure ILs. Three different approaches were used to determine unknown UNIFAC-CONDUCT parameters using the Marquardt optimization technique. All of them were then assessed using 784 conductivity data points for 38 different ILs as a function of temperature at atmospheric pressure. As expected, the method 3 , which is based on the optimization of all fitting parameters, provides the best accuracy. However, by keeping the values of $T_{0}$ and $\alpha_{m n}$ as those reported in our previous paper [41], one can appreciate their physical meanings and this approach indeed reduces the number of unknown parameters for the property estimation by developing a single set of parameters for these two UNIFAC-based methods. In addition, the derivation of the formulation between the conductivity and viscosity of ILs was presented, through the combination of the Nernst-Einstein and Stokes-Einstein equations. An excellent linear relationship between the calculated conductivity and the inverse calculated viscosity, also demonstrates the quality of both the UNIFAC-CONDUCT model proposed herein, and the UNIFAC-VISCO model previously developed by our group $[40,41]$, as well as the possibility to develop an unique set of parameters for these two related UNIFAC-based models. In addition, the conductivity of the $\left(\left[\mathrm{C}_{2} \mathrm{mim}\right][\mathrm{DCA}]+\left[\mathrm{C}_{2} \mathrm{mim}\right][\mathrm{SCN}]\right)$ binary system was purely predicted using this approach with high accuracy. This demonstrates that the UNIFAC-CONDUCT model is able to predict the conductivity of binary systems 
containing ILs. The prediction of the conductivity of electrolytes (i.e. mixtures of ILS and/or molten salts and/or molecular solvents) based on the UNIFAC-CONDUCT model is currently being investigated by our group and will be presented in the near future. 


\section{Supporting Information}

An overview of the parameters used to establish the UNIFAC-CONDUCT model in this work is presented in the Supporting Information in Table S1-S7. Effective molar volume parameters, $R$ and $Q$ values for each ion are tabulated in Tables S1 and S2, respectively, while the values of three different sets of UNIFAC-CONDUCT parameters were listed in Tables S3-S7. Furthermore, the Matlab files used for the calculation of the conductivity of pure ILs and two separated spreadsheets (named "conductivity database for pure ILs" and "calculation example") reporting the database used and an example of the calculation procedure using the UNIFAC-CONDUCT model are also provided in the Supporting Information.

\section{Corresponding Author}

Johan Jacquemin, E-mail: johan.jacquemin@qub.ac.uk or ij@univ-tours.fr

\section{Acknowledgement}

N.Z. and J.J. acknowledge gratefully the CEA le Ripault (Grant No 4600261677/P6E31) and the Engineering and Physical Sciences Research Council (EPSRC) for supporting this work financially (EPSRC First Grant Scheme, Grant No EP/M021785/1).

\section{ABBREVIATIONS}

\section{Cations:}

[C1mim $^{+}$1,3-dimethylimidazolium

$\left[\mathrm{C}_{2} \mathrm{mim}\right]^{+}$1-ethyl-3-methylimidazolium

[C $\left.\mathrm{C}_{3} \mathrm{mim}\right]^{+}$1-propyl-3-methylimidazolium 
$\left[\mathrm{C}_{4} \mathrm{mim}\right]^{+}$1-butyl-3-methylimidazolium

$\left[\mathrm{C}_{6} \text { mim }\right]^{+}$1-hexyl-3-methylimidazolium

[Comim]+ 1-octyl-3-methylimidazolium

[C10mim] ${ }^{+}$1-decyl-3-methylimidazolium

$\left[\mathrm{C}_{4} \mathrm{mmim}\right]^{+}$1-butyl-2,3-dimethylimidazolium

[C4py]+1-butylpyridinium

$\left[\mathrm{C}_{4} \mathrm{~m}_{(3)} \mathrm{py}\right]^{+}$1-butyl-3-methylpyridinium

$\left[\mathrm{C}_{4} \mathrm{~m}_{(4)} \text { py }\right]^{+}$1-butyl-4-methylpyridinium

[C4mpyrro] 1-butyl-1-methylpyrrolidinium

$\left[\mathrm{N}_{1114}\right]^{+}$butyl-trimethyl-ammonium

Anions:

$\left[\mathrm{BF}_{4}\right]^{-}$tetrafluoroborate

[NTf $]^{-}$bis(trifluoromethylsulfonyl)imide

$\left[\mathrm{C}_{1} \mathrm{SO}_{4}\right]^{-}$methylsulfate

$\left[\mathrm{C}_{2} \mathrm{SO}_{4}\right]^{-}$ethylsulfate

$\left[\mathrm{C}_{8} \mathrm{SO}_{4}\right]^{-}$octylsulfate

[PF6] ' hexafluorophosphate

[DCA]- dicyanamide

[OAc]- acetate

[OTf]- triflate

[eFAP] ${ }^{-}$tris(pentafluoroethyl)trifluorophosphate

[Tos]- tosylate 


\section{NOMENCLATURE}

Roman Letters:

$A$ VFT equation parameter

$A_{0}$ parameter in eq. 6

a parameter in eq. 2

$a_{i}$ parameter of group $i$

$B$ VFT equation parameter

$B_{0}$ parameter in eq. 7

$B_{0}^{\prime}$ parameter in eq. 7

$b_{i}$ parameter of group $i$

$C$ total number of components in UNIFAC-VISCO method

c concentration of the charge carriers

$D$ self-diffusion coefficient $\left(\mathrm{m}^{2} / \mathrm{s}\right)$

$d$ parameter in eq. 1

$e_{0}$ elementary charge

$g_{c}^{E}$ combinatorial contribution term in UNIFAC-VISCO method

$g_{r}^{E}$ residual contribution term in UNIFAC-VISCO method

$h$ parameter in eq. 1

$k_{B}$ Boltzmann constant $(\mathrm{J} / \mathrm{K})$

$n$ moles of the charge carriers

$n_{i}$ total number of $i^{\text {th }}$ group present in the IL

$n_{i, k}$ total number of $k^{\text {th }}$ group present in component $i$ 
$M$ number of data points

$N$ total number

$N_{A}$ Avogadro number $\left(\mathrm{mol}^{-1}\right)$

$Q_{k}$ group surface area parameter

$q_{i}$ van der Waals' surface area of component $i$

$r$ effective radius

$\mathcal{R}$ gas constant $(\mathrm{J} / \mathrm{mol} \cdot \mathrm{K})$

$T$ temperature (K)

$T_{0} \quad$ VFT equation parameter

$T_{0}^{\prime}$ parameter in eq. 8

$V$ volume of the charge carriers present

$V_{i}$ pure-component molar volume $\left(\mathrm{m}^{3} / \mathrm{kmol}\right)$

$V_{m}$ molar volume of ionic liquid $\left(\mathrm{m}^{3} / \mathrm{kmol}\right)$

$W A_{m, i}$ contribution of the $m^{\text {th }}$-order group $i$

$W B_{m, i}$ contribution of the $m^{\text {th }}$-order group $i$

$W B_{m, i}^{\prime}$ contribution of the $m^{\text {th }}$-order group $i$

$W T_{0 m, i}$ contribution of the $m^{\text {th }}$-order group $i$

$x_{i}$ mole fraction of the component $i$

$z$ valence of the charge carrier

Greek Letters:

$\alpha_{m n}$ interaction parameter between groups $m$ and $n$

$\beta^{X}$ substituent constant 
$\gamma_{m}$ residual activity coefficient

$\theta_{i}$ molecular surface area fraction of component $i$

$\Theta_{i}$ area fraction for group $i$

$\sigma$ conductivity $(\mathrm{S} / \mathrm{cm})$

$\sigma_{\text {exp }}$ conductivity experimentally measured

$\sigma_{c a l}$ conductivity calculated by our method

$\sigma_{i}$ conductivity of the pure component $i$

$\sigma^{X}$ conductivity of $X$-substituted IL

$\sigma^{0}$ conductivity of methyl-substituted IL

$\sigma_{c i}$ contribution of sub-structure $i$ on cations

$\sigma_{a i}$ contribution of sub-structure $i$ on anions

$\eta$ viscosity $(\mathrm{mPa} \cdot \mathrm{s})$

$\eta_{\text {cal }}$ calculated viscosity

$\phi_{i}$ molecular volume fraction of component $i$

$\Psi_{m, n}$ group interaction parameter

$\Lambda$ molar conductivity $\left(\mathrm{S} \cdot \mathrm{m}^{2} \cdot \mathrm{mol}^{-1}\right)$ 


\section{REFERENCES}

[1] P. Wasserscheid, T. Welton, lonic Liquids in Synthesis, Wiley-VCH: Weinheim, 2003.

[2] M. Watanabe, M.L. Thomas, S. Zhang, K. Ueno, T. Yasuda, K. Dokko, Application of Ionic Liquids to Energy Storage and Conversion Materials and Devices, Chem. Rev. (2017). doi:10.1021/acs.chemrev.6b00504.

[3] K.-J. Wu, H. Luo, L. Yang, Structure-based model for prediction of electrical conductivity of pure ionic liquids, AIChE J. 62 (2016) 3751-3762.

[4] J.M. Slattery, C. Daguenet, P.J. Dyson, T.J.S. Schubert, I. Krossing, How to Predict the Physical Properties of Ionic Liquids: A Volume-Based Approach, Angew. Chem. Int. Ed. 46 (2007) 5384-5388.

[5] M.G. Bogdanov, B. Iliev, W. Kantlehner, The Residual Volume Approach II: Simple Prediction of Ionic Conductivity of Ionic Liquids, Z. Naturforsch. 64b (2009) 756-764.

[6] R.L. Gardas, J.A.P. Coutinho, Group contribution methods for the prediction of thermophysical and transport properties of ionic liquids, AIChE J. 55 (2009) 1274-1290.

[7] F. Gharagheizi, P. Ilani-Kashkouli, M. Sattari, A.H. Mohammadi, D. Ramjugernath, D. Richon, Development of a LSSVM-GC model for estimating the electrical conductivity of ionic liquids, Chem. Eng. Res. Des. 92 (2014) 6679.

[8] A.P. Abbott, Application of Hole Theory to the Viscosity of Ionic and Molecular Liquids, ChemPhysChem. 5 (2004) 1242-1246.

[9] H. Zhao, Z.-C. Liang, F. Li, An improved model for the conductivity of room-temperature ionic liquids based on hole theory, J. Mol. Liq. 149 (2009) $55-59$.

[10] H. Matsuda, H. Yamamoto, K. Kurihara, K. Tochigi, Computer-aided reverse design for ionic liquids by QSPR using descriptors of group contribution type for ionic conductivities and viscosities, Fluid Phase Equilib. 261 (2007) 434443. 
[11] K. Tochigi, H. Yamamoto, Estimation of ionic conductivity and viscosity of ionic liquids using a QSPR model, J. Phys. Chem. C. 111 (2007) 15989-15994.

[12] Q. Dong, C.D. Muzny, A. Kazakov, V. Diky, J.W. Magee, J.A. Widegren, R.D. Chirico, K.N. Marsh, M. Frenkel, ILThermo: A free-access web database for thermodynamic properties of ionic liquids, J. Chem. Eng. Data. 52 (2007) 1151-1159.

[13] J. Vila, B. Fernández-Castro, E. Rilo, J. Carrete, M. Domínguez-Pérez, J.R. Rodríguez, M. García, L.M. Varela, O. Cabeza, Liquid-solid-liquid phase transition hysteresis loops in the ionic conductivity of ten imidazolium-based ionic liquids, Fluid Phase Equilib. 320 (2012) 1-10.

[14] J. Vila, P. Ginés, J.M. Pico, C. Franjo, E. Jiménez, L.M. Varela, O. Cabeza, Temperature dependence of the electrical conductivity in EMIM-based ionic liquids: Evidence of Vogel-Tamman-Fulcher behavior, Fluid Phase Equilib. 242 (2006) 141-146.

[15] I. Bandrés, D.F. Montaño, I. Gascón, P. Cea, C. Lafuente, Study of the conductivity behavior of pyridinium-based ionic liquids, Electrochim. Acta. 55 (2010) 2252-2257.

[16] H. Tokuda, S. Tsuzuki, M.A.B.H. Susan, K. Hayamizu, M. Watanabe, How ionic are room-temperature ionic liquids? An indicator of the physicochemical properties, J. Phys. Chem. B. 110 (2006) 19593-19600.

[17] Y.O. Andriyko, W. Reischl, G.E. Nauer, Trialkyl-Substituted Imidazolium-Based Ionic Liquids for Electrochemical Applications: Basic Physicochemical Properties, J. Chem. Eng. Data. 54 (2009) 855-860.

[18] H. Ning, M. Hou, Q. Mei, Y. Liu, D. Yang, B. Han, The physicochemical properties of some imidazolium-based ionic liquids and their binary mixtures, Sci. China Chem. 55 (2012) 1509-1518.

[19] M. Kanakubo, K.R. Harris, N. Tsuchihashi, K. Ibuki, M. Ueno, Temperature and pressure dependence of the electrical conductivity of the ionic liquids 1-methyl-3-octylimidazolium hexafluorophosphate and 1-methyl-3-octylimidazolium tetrafluoroborate, Fluid Phase Equilib. 261 (2007) 
414-420.

[20] S. Aparicio, R. Alcalde, B. García, J.M. Leal, High-Pressure Study of the Methylsulfate and Tosylate Imidazolium Ionic Liquids, J. Phys. Chem. B. 113 (2009) 5593-5606.

[21] B.E. Mbondo Tsamba, S. Sarraute, M. Traïkia, P. Husson, Transport Properties and Ionic Association in Pure Imidazolium-Based Ionic Liquids as a Function of Temperature, J. Chem. Eng. Data. 59 (2014) 1747-1754.

[22] Y.H. Yu, A.N. Soriano, M.H. Li, Heat capacities and electrical conductivities of 1-n-butyl-3-methylimidazolium-based ionic liquids, Thermochim. Acta. 482 (2009) 42-48.

[23] A.B. Pereiro, J.M.M. Araújo, F.S. Oliveira, C.E.S. Bernardes, J.M.S.S. Esperanca, J.N.C. Lopes, I.M. Marrucho, L.P.N. Rebelo, Inorganic salts in purely ionic liquid media: the development of high ionicity ionic liquids (HIILs), Chem. Commun. 48 (2012) 3656-3658.

[24] O. Cabeza, J. Vila, E. Rilo, M. Domínguez-Pérez, L. Otero-Cernadas, E. López-Lago, T. Méndez-Morales, L.M. Varela, Physical properties of aqueous mixtures of the ionic 1-ethl-3-methyl imidazolium octyl sulfate: A new ionic rigid gel, J. Chem. Thermodyn. 75 (2014) 52-57.

[25] Y.H. Yu, A.N. Soriano, M.H. Li, Heat capacities and electrical conductivities of 1-ethyl-3-methylimidazolium-based ionic liquids, J. Chem. Thermodyn. 41 (2009) 103-108.

[26] O. Zech, A. Stoppa, R. Buchner, W. Kunz, The Conductivity of Imidazolium-Based Ionic Liquids from (248 to 468) K. B. Variation of the Anion, J. Chem. Eng. Data. 55 (2010) 1774-1778.

[27] N. Zec, M. Bešter-Rogač, M. Vraneš, S. Gadžurić, Physicochemical properties of (1-butyl-1-methylpyrrolydinium dicyanamide $+y$-butyrolactone) binary mixtures, J. Chem. Thermodyn. 91 (2015) 327-335.

[28] J.-G. Li, Y.-F. Hu, S. Ling, J.-Z. Zhang, Physicochemical Properties of $\left[\mathrm{C}_{6} \mathrm{mim}\right]\left[\mathrm{PF}_{6}\right]$ and $\left[\mathrm{C}_{6} \mathrm{mim}\right]\left[\left(\mathrm{C}_{2} \mathrm{~F}_{5}\right)_{3} \mathrm{PF}_{3}\right]$ lonic Liquids, J. Chem. Eng. Data. 56 (2011) 30683072. 
[29] J.A. Widegren, E.M. Saurer, K.N. Marsh, J.W. Magee, Electrolytic conductivity of four imidazolium-based room-temperature ionic liquids and the effect of a water impurity, J. Chem. Thermodyn. 37 (2005) 569-575.

[30] S. Papović, M. Vraneš, S. Gadžurić, A comprehensive study of \{Y-butyrolactone + 1-methyl-3-propylimidazolium bis(trifluoromethylsulfonyl)imide\} binary mixtures, J. Chem. Thermodyn. 91 (2015) 360-368.

[31] Q.-G. Zhang, Y. Wei, S.-S. Sun, C. Wang, M. Yang, Q.-S. Liu, Y.-A. Gao, Study on Thermodynamic Properties of Ionic Liquid N-Butyl-3-methylpyridinium Bis(trifluoromethylsulfonyl)imide, J. Chem. Eng. Data. 57 (2012) 2185-2190.

[32] Q.-S. Liu, P.-P. Li, U. Welz-Biermann, X.-X. Liu, J. Chen, Density, Electrical Conductivity, and Dynamic Viscosity of N-Alkyl-4-methylpyridinium Bis(trifluoromethylsulfonyl)imide, J. Chem. Eng. Data. 57 (2012) 2999-3004.

[33] M. Kanakubo, K.R. Harris, N. Tsuchihashi, K. Ibuki, M. Ueno, Temperature and Pressure Dependence of the Electrical Conductivity of 1-Butyl-3-methylimidazolium Bis(trifluoromethanesulfonyl)amide, J. Chem. Eng. Data. 60 (2015) 1495-1503.

[34] M. Vranes, S. Dozic, V. Djeric, S. Gadzuric, Physicochemical Characterization of 1-Butyl-3-methylimidazolium and 1-Butyl-1-methylpyrrolidinium Bis(trifluoromethylsulfonyl)imide, J. Chem. Eng. Data. 57 (2012) 1072-1077.

[35] Q.G. Zhang, S.S. Sun, S. Pitula, Q.S. Liu, U. Welz-Biermann, J.J. Zhang, Electrical conductivity of solutions of ionic liquids with methanol, ethanol, acetonitrile, and propylene carbonate, J. Chem. Eng. Data. 56 (2011) 4659-4664.

[36] A. Nazet, S. Sokolov, T. Sonnleitner, T. Makino, M. Kanakubo, R. Buchner, Densities, Viscosities, and Conductivities of the Imidazolium Ionic Liquids $[$ Emim $][A c],[$ Emim $][F A P],[B m i m][B E T I],[B m i m][F S I], \quad[H \operatorname{Him}][T F S I]$, and [Omim][TFSI], J. Chem. Eng. Data. 60 (2015) 2400-2411.

[37] J.M.M. Araújo, A.B. Pereiro, F. Alves, I.M. Marrucho, L.P.N. Rebelo, Nucleic acid bases in 1-alkyl-3-methylimidazolium acetate ionic liquids: $A$ thermophysical and ionic conductivity analysis, J. Chem. Thermodyn. 57 (2013) 1-8. 
[38] M. Kanakubo, K.R. Harris, N. Tsuchihashi, K. Ibuki, M. Ueno, Effect of Pressure on Transport Properties of the Ionic Liquid 1-Butyl-3-methylimidazolium Hexafluorophosphate, J. Phys. Chem. B. 111 (2007) 2062-2069.

[39] K.R. Harris, M. Kanakubo, N. Tsuchihashi, K. Ibuki, M. Ueno, Effect of pressure on the transport properties of ionic liquids: 1-alkyl-3-methylimidazolium salts., J. Phys. Chem. B. 112 (2008) 9830-9840.

[40] N. Zhao, J. Jacquemin, R. Oozeerally, V. Degirmenci, New Method for the Estimation of Viscosity of Pure and Mixtures of Ionic Liquids Based on the UNIFAC-VISCO Model, J. Chem. Eng. Data. 61 (2016) 2160-2169.

[41] N. Zhao, R. Oozeerally, V. Degirmenci, Z. Wagner, M. Bendová, J. Jacquemin, New Method Based on the UNIFAC-VISCO Model for the Estimation of Ionic Liquids Viscosity Using the Experimental Data Recommended by Mathematical Gnostics, J. Chem. Eng. Data. 61 (2016) 3908-3921.

[42] S. Bulut, P. Eiden, W. Beichel, J.M. Slattery, T.F. Beyersdorff, T.J.S. Schubert, I. Krossing, Temperature Dependence of the Viscosity and Conductivity of Mildly Functionalized and Non-Functionalized $\left[\mathrm{Tf}_{2} \mathrm{~N}\right]^{-}$Ionic Liquids, ChemPhysChem. 12 (2011) 2296-2310.

[43] J. Jacquemin, P. Nancarrow, D.W. Rooney, M.F. Costa Gomes, P. Husson, V. Majer, A.A.H. Pádua, C. Hardacre, Prediction of Ionic Liquid Properties. II. Volumetric Properties as a Function of Temperature and Pressure, J. Chem. Eng. Data. 53 (2008) 2133-2143.

[44] J. Jacquemin, R. Ge, P. Nancarrow, D.W. Rooney, M.F. Costa Gomes, A.A.H. Pádua, C. Hardacre, Prediction of Ionic Liquid Properties. I. Volumetric Properties as a Function of Temperature at $0.1 \mathrm{MPa}$, J. Chem. Eng. Data. 53 (2008) 716-726.

[45] Y. Wang, W. Hao, J. Jacquemin, P. Goodrich, M. Atilhan, M. Khraisheh, D. Rooney, J. Thompson, Enhancing Liquid-Phase Olefin-Paraffin Separations Using Novel Silver-Based Ionic Liquids, J. Chem. Eng. Data. 60 (2015) 28-36.

[46] D.W. Marquardt, An Algorithm for Least-Squares Estimation of Nonlinear Parameters, J. Soc. Indust. Appl. Math. 11 (1963) 431-441. 
[47] P.D.A. Bastos, F.S. Oliveira, L.P.N. Rebelo, A.B. Pereiro, I.M. Marrucho, Separation of azeotropic mixtures using high ionicity ionic liquids based on 1-ethyl-3-methylimidazolium thiocyanate, Fluid Phase Equilib. 389 (2015) 4854. 
Table 1. An overview of the experimental conductivity data used to establish the UNIFAC-CONDUCT model in this work

\begin{tabular}{|c|c|c|c|c|}
\hline Ionic Liquid & $T / \mathrm{K}$ & No. of data points & $\sigma / \mathrm{S} \cdot \mathrm{m}^{-1}$ & Ref. \\
\hline$\left[\mathrm{C}_{10 \mathrm{mim}}\right]\left[\mathrm{BF}_{4}\right]$ & 263.1-353.1 & 34 & $0.00236-0.409$ & [13] \\
\hline$\left[\mathrm{C}_{2} \mathrm{mim}\right]\left[\mathrm{BF}_{4}\right]$ & 258.1-433.1 & 36 & $0.245-12.68$ & [14] \\
\hline$\left[\mathrm{C}_{4} \mathrm{~m}_{(3)} \mathrm{py}\right]\left[\mathrm{BF}_{4}\right]$ & $278.15-338.15$ & 25 & $0.0495-1.193$ & [15] \\
\hline$\left[\mathrm{C}_{4} \mathrm{~m}_{(4)} \mathrm{py}\right]\left[\mathrm{BF}_{4}\right]$ & $278.15-338.15$ & 25 & $0.0381-1.211$ & [15] \\
\hline$\left[\mathrm{C}_{4} \mathrm{mim}\right]\left[\mathrm{BF}_{4}\right]$ & $263.15-373.15$ & 10 & $0.036-3.4$ & [16] \\
\hline$\left[\mathrm{C}_{4} \mathrm{mmim}\right]\left[\mathrm{BF}_{4}\right]$ & $303.15-368.15$ & 14 & $0.0758-1.5511$ & [17] \\
\hline$\left[\mathrm{C}_{4} \mathrm{py}\right]\left[\mathrm{BF}_{4}\right]$ & $278.15-338.15$ & 25 & $0.0591-1.311$ & [15] \\
\hline$\left[\mathrm{C}_{6} \mathrm{mim}\right]\left[\mathrm{BF}_{4}\right]$ & 303-333 & 7 & $0.1598-0.576$ & [18] \\
\hline$\left[\mathrm{C}_{8} \mathrm{mim}\right]\left[\mathrm{BF}_{4}\right]$ & $273.23-353.21$ & 57 & $0.00961-0.5806$ & [19] \\
\hline$\left[\mathrm{C}_{1} \mathrm{mim}\right]\left[\mathrm{C}_{1} \mathrm{SO}_{4}\right]$ & $278.15-368.15$ & 10 & $0.1449-2.53$ & [20] \\
\hline$\left[\mathrm{C}_{2} \mathrm{mim}\right]\left[\mathrm{C}_{1} \mathrm{SO}_{4}\right]$ & $298.15-343.15$ & 6 & $0.602-2.336$ & [21] \\
\hline$\left[\mathrm{C}_{4} \mathrm{mim}\right]\left[\mathrm{C}_{1} \mathrm{SO}_{4}\right]$ & $303.2-353.2$ & 11 & $0.217-1.667$ & [22] \\
\hline$\left[\mathrm{C}_{2} \mathrm{mim}\right]\left[\mathrm{C}_{2} \mathrm{SO}_{4}\right]$ & $298.15-323.15$ & 6 & $0.3798-1.0005$ & [23] \\
\hline$\left[\mathrm{C}_{2} \mathrm{mim}\right]\left[\mathrm{C}_{8} \mathrm{SO}_{4}\right]$ & 258.1-373.1 & 24 & $0.002-0.731$ & [24] \\
\hline$\left[\mathrm{C}_{2} \mathrm{mim}\right][\mathrm{DCA}]$ & $293.2-353.2$ & 11 & $1.89-6.86$ & [25] \\
\hline$\left[\mathrm{C}_{4} \mathrm{~m}_{(3) \mathrm{py}}\right][\mathrm{DCA}]$ & $288.15-338.15$ & 21 & $0.526-2.91$ & [15] \\
\hline$\left[\mathrm{C}_{4} \mathrm{mim}\right][\mathrm{DCA}]$ & $248.15-468.15$ & 23 & $0.0483-14.54$ & [26] \\
\hline$\left[\mathrm{C}_{4} \mathrm{mpyrro}\right][\mathrm{DCA}]$ & $273.15-323.15$ & 11 & $0.523-2.529$ & [27] \\
\hline$\left[\mathrm{C}_{6} \mathrm{mim}\right][\mathrm{eFAP}]$ & $293.15-343.15$ & 11 & $0.1303-0.769$ & [28] \\
\hline$\left[\mathrm{C}_{1} \mathrm{mim}\right]\left[\mathrm{NTf}_{2}\right]$ & $293.15-373.15$ & 7 & $0.75-4.3$ & [16] \\
\hline$\left[\mathrm{C}_{2} \mathrm{mim}\right]\left[\mathrm{NTf} f_{2}\right]$ & $288.15-323.15$ & 5 & $0.644-1.789$ & [29] \\
\hline$\left[\mathrm{C}_{3} \mathrm{mim}\right]\left[\mathrm{NTf} f_{2}\right]$ & $293.15-323.15$ & 7 & $0.355-0.923$ & [30] \\
\hline$\left[\mathrm{C}_{4} \mathrm{~m}_{(3)} \mathrm{py}\right]\left[\mathrm{NTf}_{2}\right]$ & $278.15-353.15$ & 16 & $0.1-1.437$ & [31] \\
\hline$\left[\mathrm{C}_{4} \mathrm{~m}_{(4) \mathrm{py}}\right]\left[\mathrm{NTf}_{2}\right]$ & $278.15-338.15$ & 13 & $0.124-1.207$ & [32] \\
\hline$\left[\mathrm{C}_{4} \mathrm{mim}\right]\left[\mathrm{NTf}_{2}\right]$ & $273.15-353.17$ & 58 & $0.1181-1.796$ & [33] \\
\hline$\left[\mathrm{C}_{4} \mathrm{mpyrro}\right]\left[\mathrm{NTf}_{2}\right]$ & $298.15-353.15$ & 56 & $0.277-1.492$ & [34] \\
\hline$\left[\mathrm{C}_{4} \mathrm{py}\right]\left[\mathrm{NTf}_{2}\right]$ & $283.15-313.15$ & 10 & $0.15-0.542$ & [35] \\
\hline
\end{tabular}


Table 1. Continued ...

\begin{tabular}{|c|c|c|c|c|}
\hline Ionic Liquid & $T / \mathrm{K}$ & No. of data points & $\sigma / \mathrm{s} \cdot \mathrm{m}^{-1}$ & Ref. \\
\hline$\left[\mathrm{C}_{6} \mathrm{mim}\right]\left[\mathrm{NTf}_{2}\right]$ & $278.15-468.15$ & 20 & $0.07762-5.237$ & [36] \\
\hline$\left[\mathrm{C}_{8} \mathrm{mim}\right]\left[\mathrm{NTf}_{2}\right]$ & $273.15-468.15$ & 29 & $0.03083-4.029$ & [36] \\
\hline$\left[\mathrm{N}_{1114}\right]\left[\mathrm{NTf}_{2}\right]$ & $263.15-373.15$ & 10 & $0.021-1.8$ & [16] \\
\hline$\left[\mathrm{C}_{2} \mathrm{mim}\right][\mathrm{OAc}]$ & 298.15-418.15 & 13 & $0.2776-6.917$ & [36] \\
\hline$\left[\mathrm{C}_{4} \mathrm{mim}\right][\mathrm{OAc}]$ & $283.15-323.15$ & 9 & $0.0131-0.221$ & [37] \\
\hline$\left[\mathrm{C}_{2} \operatorname{mim}\right][\mathrm{OTf}]$ & 293.2-353.2 & 11 & $0.834-3.51$ & [25] \\
\hline$\left[\mathrm{C}_{4} \operatorname{mim}\right][\mathrm{OTf}]$ & $268.15-468.15$ & 21 & $0.0539-7.5$ & [26] \\
\hline$\left[\mathrm{C}_{4} \operatorname{mim}\right]\left[\mathrm{PF}_{6}\right]$ & $298.14-353.12$ & 17 & $0.1379-1.1345$ & [38] \\
\hline$\left[\mathrm{C}_{6} \mathrm{mim}\right]\left[\mathrm{PF}_{6}\right]$ & $273.21-353.18$ & 48 & $0.0075-0.62102$ & [39] \\
\hline$\left[\mathrm{C}_{8} \mathrm{mim}\right]\left[\mathrm{PF}_{6}\right]$ & 273.2-353.17 & 57 & $0.00325-0.3598$ & [19] \\
\hline$\left[\mathrm{C}_{2} \mathrm{mim}\right][\mathrm{Tos}]$ & $278.15-368.15$ & 10 & $0.0183-1.173$ & [20] \\
\hline
\end{tabular}


Table 2. Experimental Data Collected from Bastos et al. [47] Used During the Prediction of the Conductivity of the $\left(x\left[\mathrm{C}_{2} \mathrm{mim}\right][\mathrm{DCA}]+(1-x)\left[\mathrm{C}_{2} \mathrm{mim}\right][\mathrm{SCN}]\right)$ Binary Mixture

\begin{tabular}{|c|c|c|c|c|c|c|}
\hline \multirow[b]{2}{*}{ Temp. (K) } & \multicolumn{2}{|c|}{$x=0.2397$} & \multicolumn{2}{|c|}{$x=0.4888$} & \multicolumn{2}{|c|}{$x=0.7415$} \\
\hline & $\begin{array}{c}\sigma_{\exp } \\
\left(\mathrm{S} \cdot \mathrm{cm}^{-1}\right)\end{array}$ & $\begin{array}{c}\sigma_{c a l} \\
\left(\mathrm{~S} \cdot \mathrm{cm}^{-1}\right)\end{array}$ & $\begin{array}{c}\sigma_{\exp } \\
\left(\mathrm{S} \cdot \mathrm{cm}^{-1}\right)\end{array}$ & $\begin{array}{c}\sigma_{c a l} \\
\left(\mathrm{~S} \cdot \mathrm{cm}^{-1}\right)\end{array}$ & $\begin{array}{c}\sigma_{\exp } \\
\left(\mathrm{S} \cdot \mathrm{cm}^{-1}\right)\end{array}$ & $\begin{array}{c}\sigma_{c a l} \\
\left(\mathrm{~S} \cdot \mathrm{cm}^{-1}\right)\end{array}$ \\
\hline 298.15 & 0.0241 & 0.0242 & 0.0251 & 0.0241 & 0.0268 & 0.0248 \\
\hline 303.15 & 0.0276 & 0.0278 & 0.0289 & 0.0276 & 0.0305 & 0.0282 \\
\hline 308.15 & 0.0314 & 0.0317 & 0.0327 & 0.0313 & 0.0345 & 0.0319 \\
\hline 313.15 & 0.0356 & 0.0359 & 0.0367 & 0.0353 & 0.0387 & 0.0359 \\
\hline 318.15 & 0.0402 & 0.0404 & 0.0415 & 0.0396 & 0.0433 & 0.0400 \\
\hline 323.15 & 0.0448 & 0.0451 & 0.0462 & 0.0441 & 0.0481 & 0.0445 \\
\hline RAAD\% (each set) & \multicolumn{2}{|c|}{$0.71 \%$} & \multicolumn{2}{|c|}{$4.19 \%$} & \multicolumn{2}{|c|}{$7.50 \%$} \\
\hline RAAD\% (global) & \multicolumn{6}{|c|}{$4.13 \%$} \\
\hline
\end{tabular}




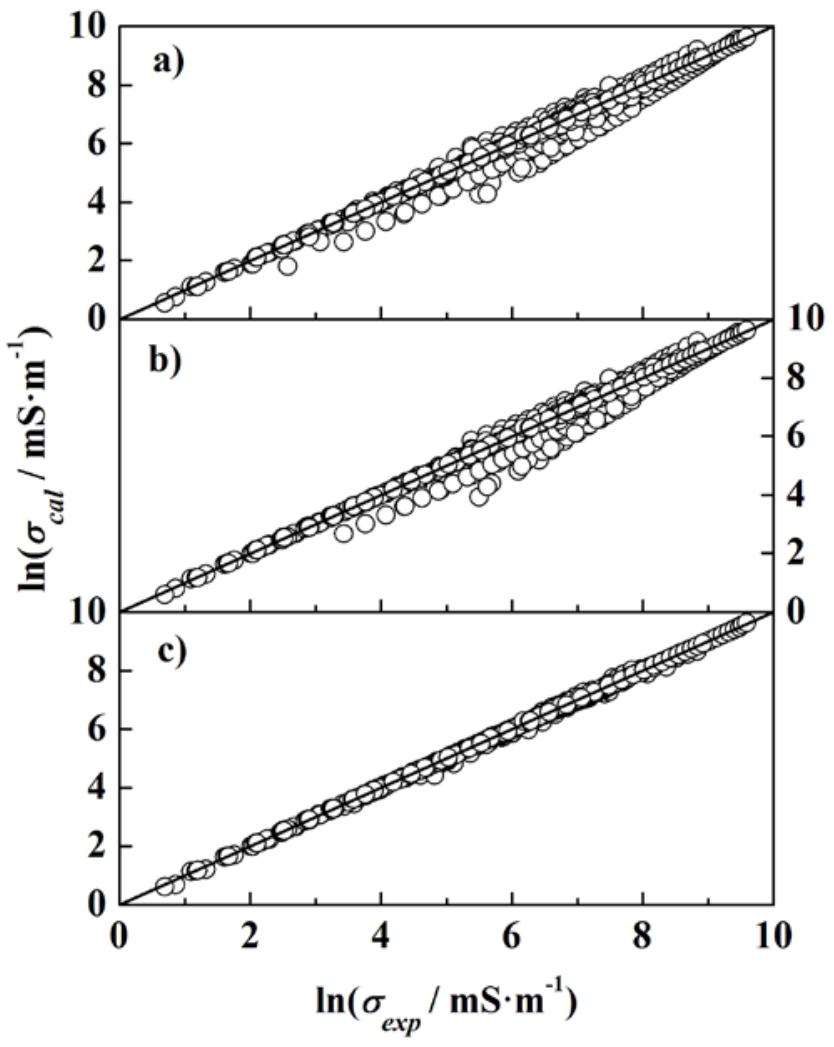

Figure 1. Comparison of experimental $\left(\sigma_{\text {exp }}\right)$ and evaluated $\left(\sigma_{c a l}\right)$ conductivity data for pure ILs by using a) method $1 ; \mathrm{b}$ ) method 2; and c) method 3 as described in sections 2.2, 2.3 and 2.4 , respectively. 


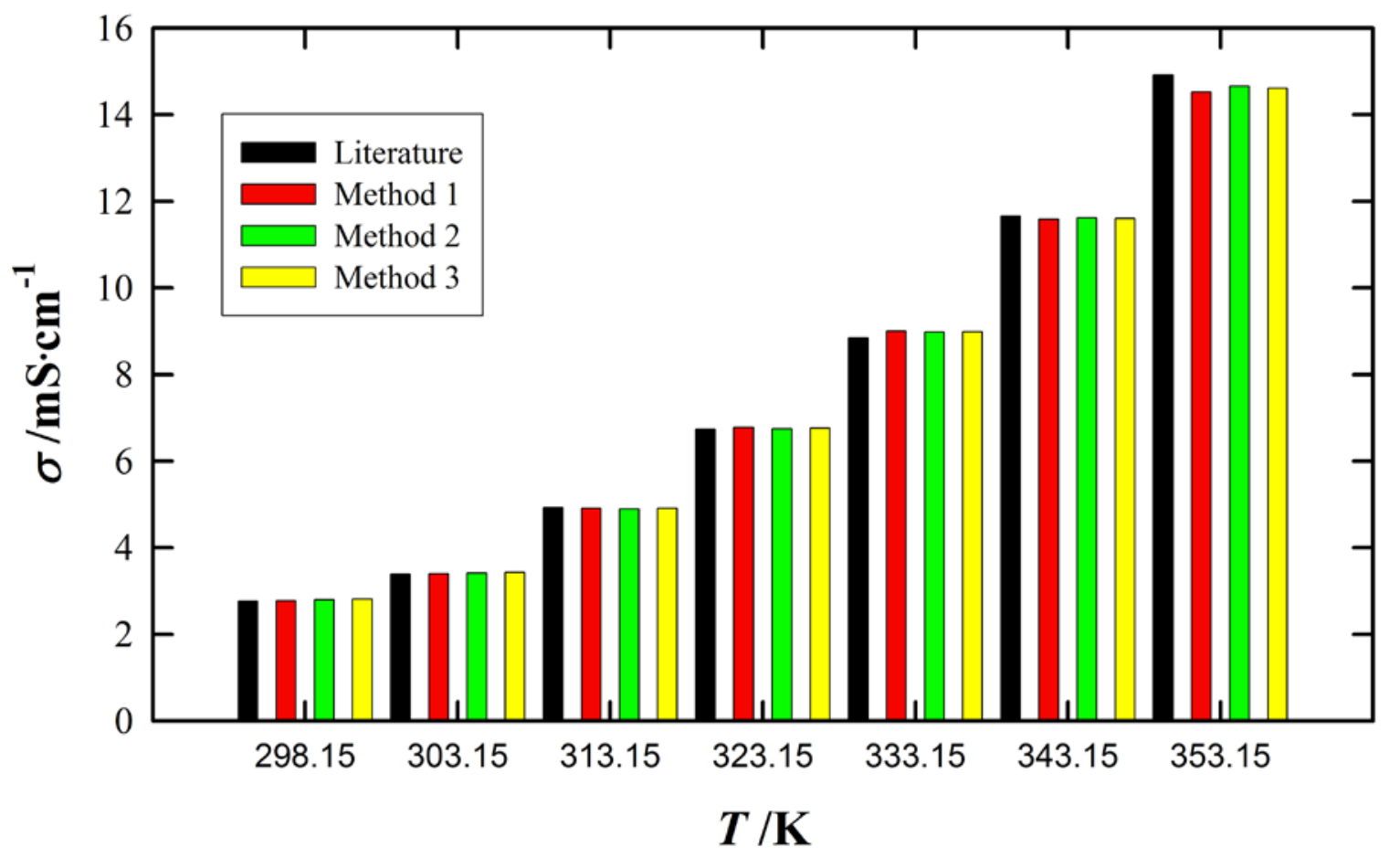

Figure 2. Comparison of the temperature dependence on the conductivity data of the $\left[\mathrm{C}_{4}\right.$ mpyrro] $\left[\mathrm{NTf}_{2}\right]$ from the literature [34] and the UNIFAC-CONDUCT model approaches investigated during this work. 


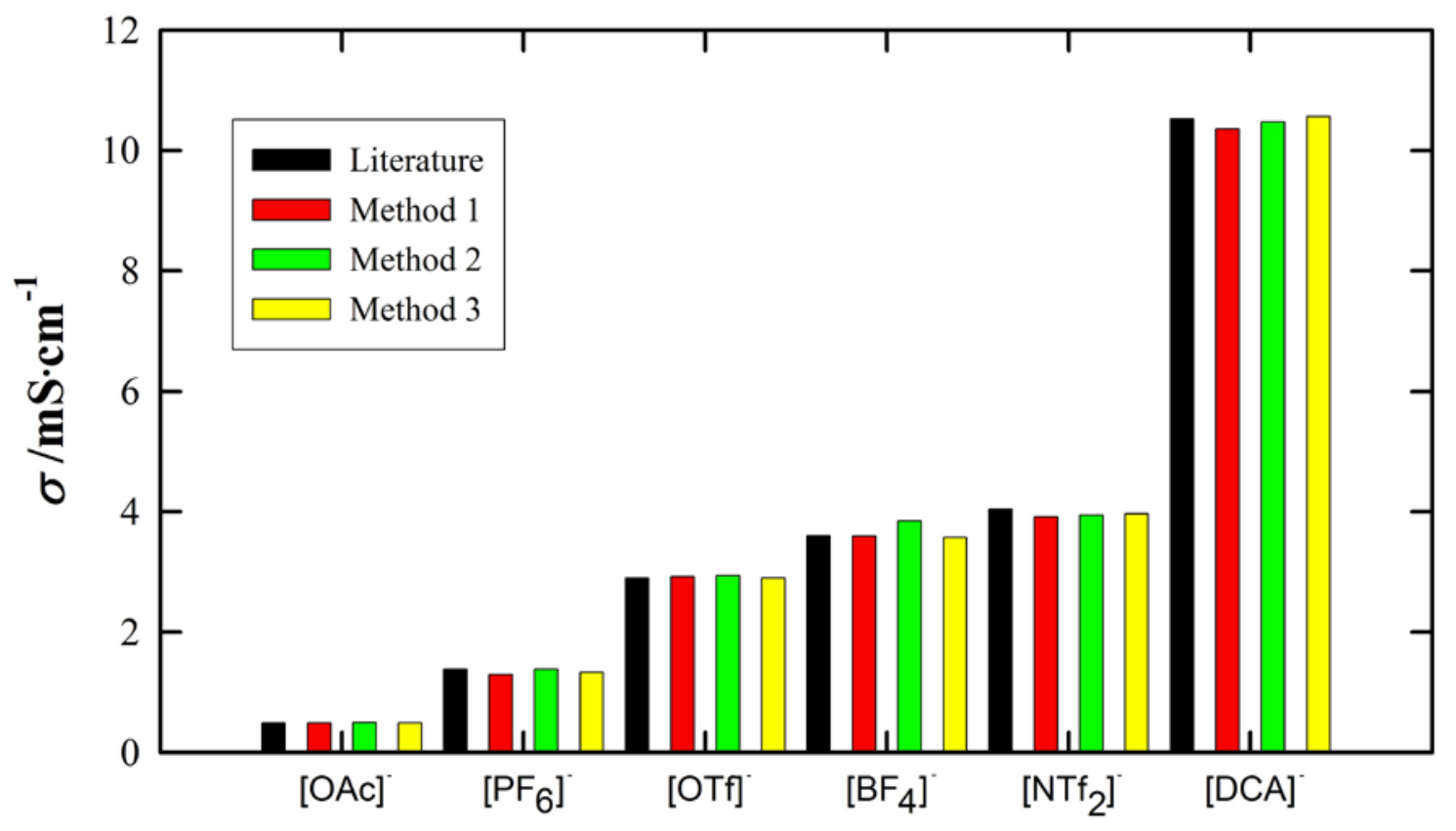

Figure 3. Comparison of the effect of anion structure on the conductivity data of $\left[\mathrm{C}_{4} \mathrm{mim}\right]^{+}-$ based ILs at $298.15 \mathrm{~K}$ from the literature $[16,26,33,37,38]$ and the UNIFAC-CONDUCT model approaches investigated during this work. 


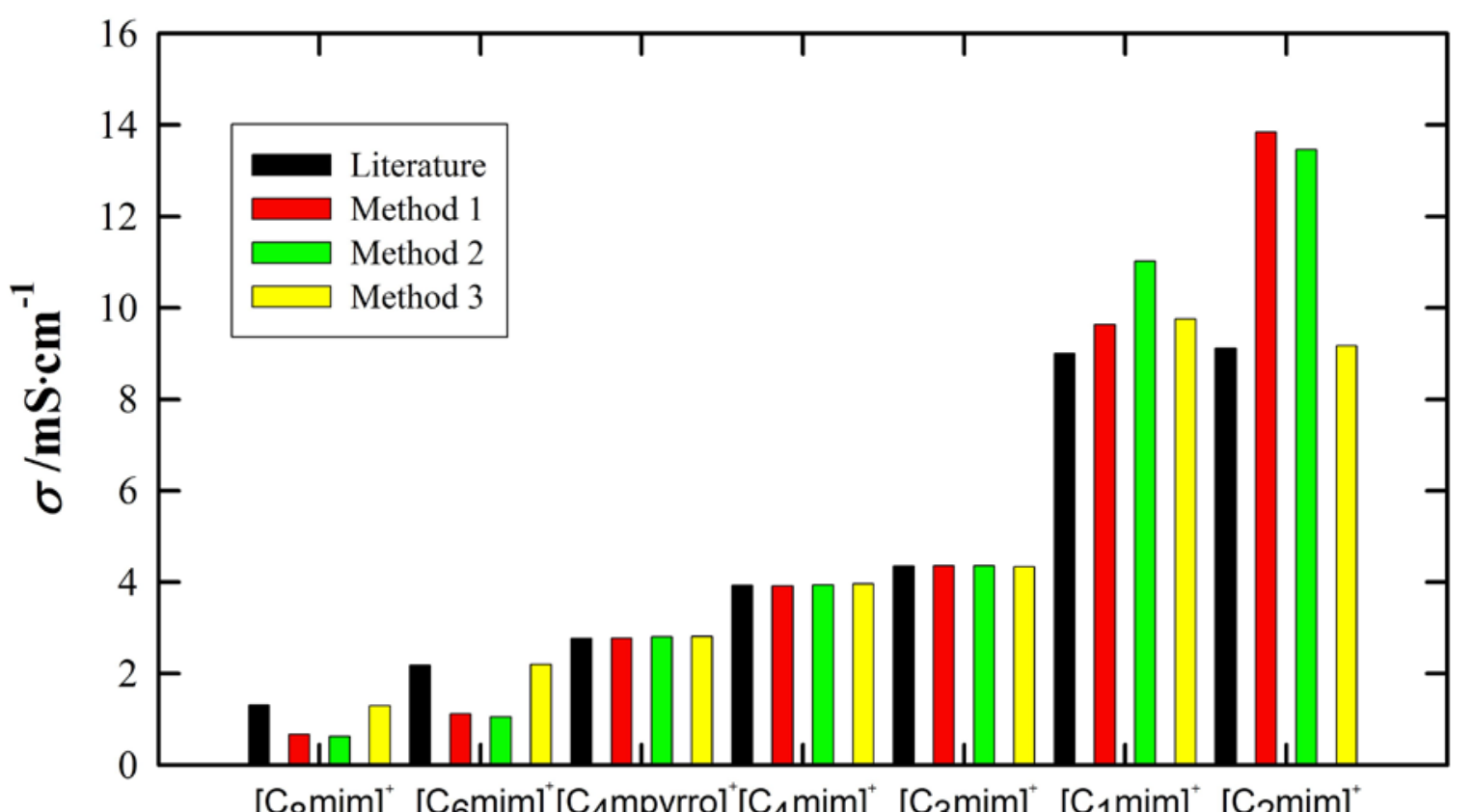

Figure 4. Comparison of the effect of cation structure on the conductivity data of $\left[\mathrm{NTf}_{2}\right]^{-}-$based ILs at $298.15 \mathrm{~K}$ from the literature $[16,29,30,33,34,36]$ and the UNIFAC-CONDUCT model approaches investigated during this work. 


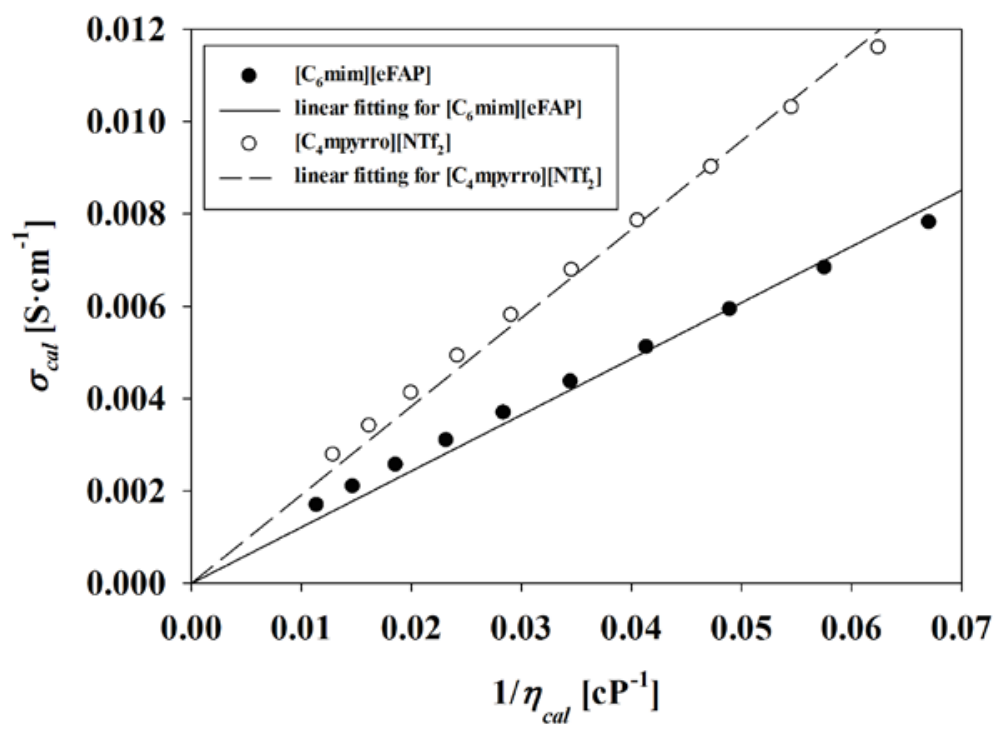

Figure 5. Calculated conductivity as a function of the inverse calculated viscosity for $\left[\mathrm{C}_{6} \mathrm{mim}\right][\mathrm{eFAP}]$ and $\left[\mathrm{C}_{4} \mathrm{mpyrro}\right]\left[\mathrm{NTf}_{2}\right]$. 


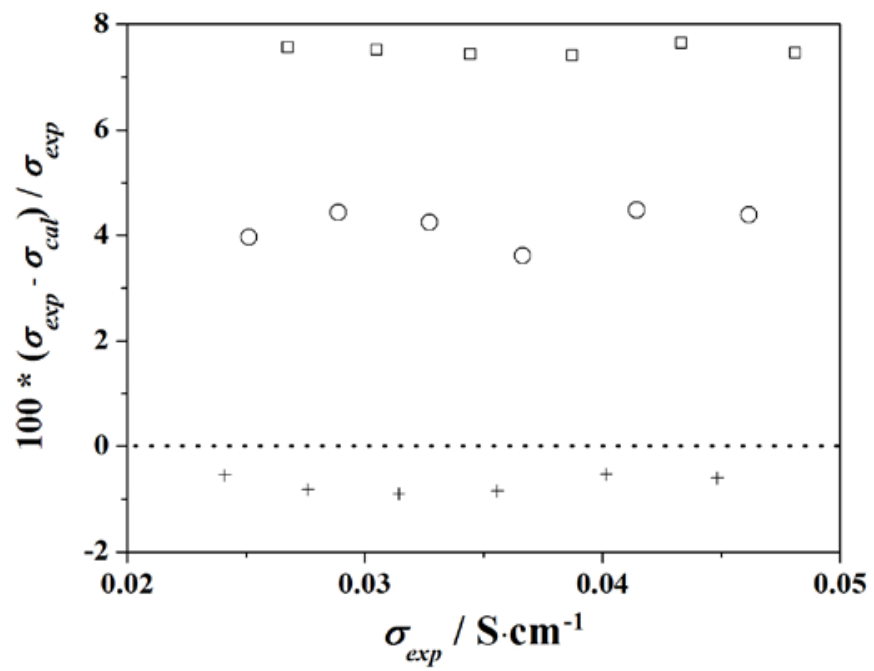

Figure 6. Relative deviations between the purely predicted values $\left(\sigma_{\text {cal }}\right)$ and the experimental conductivity data $\left(\sigma_{\text {exp }}\right)$ of the binary system $\left(x\left[\mathrm{C}_{2} \mathrm{mim}\right][\mathrm{DCA}]+(1-x)\left[\mathrm{C}_{2} \mathrm{mim}\right][\mathrm{SCN}]\right)$ from $[47]$ as a function of temperature $(298.15 \mathrm{~K}-323.15 \mathrm{~K})$ and composition:,$+ x=0.2397 ; 0, x=0.4888$; $\square, x=0.7415$. 
Supporting Information

The Development of the UNIFAC-CONDUCT Model as a Novel Approach for the Estimation of the Conductivity of Pure Ionic Liquids

\author{
Nan Zhao ${ }^{1}$, Johan Jacquemin ${ }^{1,2,{ }^{*}}$
}

${ }^{1}$ School of Chemistry and Chemical Engineering, Queen's University Belfast, Belfast, BT9 5AG, U.K.

2 Université Francois Rabelais, Laboratoire PCM2E, Parc de Grandmont 37200 Tours, France 
Table S1. Parameters of effective molar volume for cations and anions

\begin{tabular}{|c|c|c|c|c|}
\hline \multirow{2}{*}{ Ion } & $D_{0}$ & $D_{1}$ & $D_{2}$ & \multirow{2}{*}{ RAAD } \\
\hline & $\mathrm{cm}^{3} \cdot \mathrm{mol}^{-1}$ & $\mathrm{~cm}^{3} \cdot \mathrm{mol}^{-1} \cdot \mathrm{K}^{-1}$ & $\mathrm{~cm}^{3} \cdot \mathrm{mol}^{-1} \cdot \mathrm{K}^{-2}$ & \\
\hline$\left[\mathrm{C}_{1} \mathrm{mim}\right]^{+}$ & 84.61 & 0.0367 & $7.72 \mathrm{E}-05$ & 0 \\
\hline$\left[\mathrm{C}_{2} \mathrm{mim}\right]^{+}$ & 100.25 & 0.0656 & 4.57E-05 & $2.40 \mathrm{E}-04$ \\
\hline$\left[\mathrm{C}_{3} \mathrm{mim}\right]^{+}$ & 117.14 & 0.0445 & $1.18 \mathrm{E}-03$ & 0 \\
\hline$\left[\mathrm{C}_{4} \mathrm{mim}\right]^{+}$ & 134.11 & 0.0927 & $-2.99 \mathrm{E}-05$ & $2.26 \mathrm{E}-03$ \\
\hline$\left[\mathrm{C}_{6} \mathrm{mim}\right]^{+}$ & 168.60 & 0.1131 & 4.93E-05 & 7.83E-04 \\
\hline$\left[\mathrm{C}_{8} \mathrm{mim}\right]^{+}$ & 202.14 & 0.1852 & $-3.53 E-04$ & $3.02 \mathrm{E}-03$ \\
\hline$\left[\mathrm{C}_{10} \mathrm{mim}\right]^{+}$ & 236.36 & 0.1748 & 1.76E-04 & 0 \\
\hline$\left[\mathrm{C}_{4} \mathrm{mmim}^{+}\right.$ & 147.30 & 0.0974 & $6.75 \mathrm{E}-05$ & 1.97E-03 \\
\hline$\left[\mathrm{C}_{4} \mathrm{py}\right]^{+}$ & 129.98 & 0.0799 & $2.60 \mathrm{E}-05$ & 4.17E-03 \\
\hline$\left[\mathrm{C}_{4} \mathrm{~m}_{(3)} \mathrm{py}\right]^{+}$ & 146.72 & 0.0900 & $8.61 \mathrm{E}-05$ & 3.06E-04 \\
\hline$\left[\mathrm{C}_{4} \mathrm{~m}_{(4)} \mathrm{py}\right]^{+}$ & 145.73 & 0.0907 & $3.82 \mathrm{E}-05$ & $1.50 \mathrm{E}-03$ \\
\hline 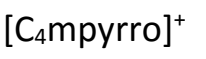 & 145.15 & 0.0929 & $-7.70 \mathrm{E}-06$ & $2.75 \mathrm{E}-03$ \\
\hline$\left[\mathrm{N}_{1114}\right]^{+}$ & 127.14 & 0.0772 & $6.94 \mathrm{E}-05$ & 0 \\
\hline$\left[\mathrm{BF}_{4}\right]^{-}$ & 53.75 & 0.0258 & $-3.40 \mathrm{E}-05$ & $1.31 \mathrm{E}-03$ \\
\hline$\left[\mathrm{C}_{1} \mathrm{SO}_{4}\right]^{-}$ & 72.32 & 0.0429 & $-8.86 \mathrm{E}-05$ & $1.76 \mathrm{E}-03$ \\
\hline$\left[\mathrm{NTf}_{2}\right]^{-}$ & 157.60 & 0.1043 & 5.05E-05 & 0 \\
\hline$\left[\mathrm{PF}_{6}\right]^{-}$ & 72.85 & 0.0363 & $-3.84 E-05$ & $1.93 \mathrm{E}-03$ \\
\hline$[D C A]^{-}$ & 59.59 & 0.0237 & 4.49E-05 & $1.95 \mathrm{E}-03$ \\
\hline$\left[\mathrm{Tos}^{-}\right.$ & 130.89 & 0.0582 & $-1.21 \mathrm{E}-04$ & 0 \\
\hline$[\mathrm{OAc}]^{-}$ & 54.44 & 0.0237 & $-7.98 \mathrm{E}-05$ & 4.97E-04 \\
\hline [OTf] $^{-}$ & 89.02 & 0.0628 & $-3.66 \mathrm{E}-05$ & 7.01E-03 \\
\hline [eFAP] $^{-}$ & 225.74 & 0.1651 & $-2.71 E-06$ & $1.89 \mathrm{E}-03$ \\
\hline$\left[\mathrm{C}_{2} \mathrm{SO}_{4}\right]^{-}$ & 90.72 & 0.0394 & $-1.66 \mathrm{E}-05$ & 0 \\
\hline$\left[\mathrm{C}_{8} \mathrm{SO}_{4}\right]^{-}$ & 192.36 & 0.0741 & $3.15 \mathrm{E}-04$ & 0 \\
\hline
\end{tabular}


Table S2. The UNIFAC-CONDUCT volume $(R)$ and surface area $(Q)$ parameters for cations and anions

\begin{tabular}{ccc}
\hline lon & $R$ & $Q$ \\
\hline$\left[\mathrm{C}_{1} \mathrm{mim}^{+}\right.$ & 4.1183 & 3.4946 \\
{$\left[\mathrm{C}_{2} \mathrm{mim}\right]^{+}$} & 4.7608 & 4.0087 \\
{$\left[\mathrm{C}_{3} \mathrm{mim}\right]^{+}$} & 5.4342 & 4.5473 \\
{$\left[\mathrm{C}_{4} \mathrm{mim}\right]^{+}$} & 6.1040 & 5.0832 \\
{$\left[\mathrm{C}_{6} \mathrm{mim}^{+}\right.$} & 7.4623 & 6.1698 \\
{$\left[\mathrm{C}_{8} \mathrm{mim}\right]^{+}$} & 8.8143 & 7.2515 \\
{$\left[\mathrm{C}_{10} \mathrm{mim}\right]^{+}$} & 10.1662 & 8.3329 \\
{$\left[\mathrm{C}_{4} \mathrm{mmim}^{+}\right.$} & 6.7595 & 5.6076 \\
{$\left[\mathrm{C}_{4} \mathrm{py}^{+}\right.$} & 5.9737 & 4.9790 \\
{$\left[\mathrm{C}_{4} \mathrm{~m}_{(3)} \mathrm{py}\right]^{+}$} & 6.6210 & 5.4968 \\
{$\left[\mathrm{C}_{4} \mathrm{~m}_{(4)} \mathrm{py}\right]^{+}$} & 6.6310 & 5.5048 \\
{$\left[\mathrm{C}_{4} \mathrm{mpyrro}^{+}\right.$} & 6.6061 & 5.4849 \\
{$\left[\mathrm{~N}_{1114}\right]^{+}$} & 5.6947 & 4.7558 \\
{$\left[\mathrm{BF}_{4}\right]^{-}$} & 2.2421 & 1.9937 \\
{$\left[\mathrm{C}_{1} \mathrm{SO}_{4}\right]^{-}$} & 3.1995 & 2.7596 \\
{$\left[\mathrm{NTf}_{2}\right]^{-}$} & 6.7937 & 5.6350 \\
{$\left[\mathrm{PF}_{6}\right]^{-}$} & 3.1900 & 2.7520 \\
{$\left[\mathrm{DCA}^{-}\right.$} & 2.5346 & 2.2277 \\
{$\left[\mathrm{Tos}^{-}\right.$} & 5.7510 & 4.8008 \\
{$[\mathrm{OAc}]^{-}$} & 2.2192 & 1.9754 \\
{$\left[\mathrm{OTf}^{-}\right.$} & 3.9625 & 3.3700 \\
{$\left[\mathrm{eFAP}^{-}\right.$} & 9.8900 & 8.1120 \\
{$\left[\mathrm{C}_{2} \mathrm{SO}_{4}\right]^{-}$} & 3.8506 & 3.2805 \\
{$\left[\mathrm{C}_{8} \mathrm{SO}_{4}\right]^{-}$} & 7.9095 & 6.5276 \\
\hline & & \\
& &
\end{tabular}


Table S3. Binary interaction parameters $\alpha_{m n}$ used in the first method and second method

\begin{tabular}{|c|c|c|c|}
\hline$m$ & $n$ & $\alpha_{m n}$ & $\alpha_{n m}$ \\
\hline$\left[\mathrm{C}_{10 \mathrm{mim}}\right]^{+}$ & {$\left[\mathrm{BF}_{4}\right]^{-}$} & 77.85 & -410.46 \\
\hline$\left[\mathrm{C}_{1} \text { mim }\right]^{+}$ & {$\left[\mathrm{NTf}_{2}\right]^{-}$} & -391.35 & 931.41 \\
\hline$\left[\mathrm{C}_{1} \mathrm{mim}\right]^{+}$ & {$\left[\mathrm{C}_{1} \mathrm{SO}_{4}\right]^{-}$} & -158.30 & -54.69 \\
\hline$\left[\mathrm{C}_{2} \mathrm{mim}\right]^{+}$ & {$\left[\mathrm{BF}_{4}\right]^{-}$} & -222.19 & -130.81 \\
\hline$\left[\mathrm{C}_{2} \mathrm{mim}\right]^{+}$ & {$\left[\mathrm{C}_{1} \mathrm{SO}_{4}\right]^{-}$} & 566.37 & -354.46 \\
\hline$\left[\mathrm{C}_{2} \mathrm{mim}\right]^{+}$ & {$\left[\mathrm{NTf}_{2}\right]^{-}$} & -322.07 & 1978.2 \\
\hline$\left[\mathrm{C}_{2} \mathrm{mim}\right]^{+}$ & {$[\mathrm{OAc}]^{-}$} & -611.17 & 6394.8 \\
\hline$\left[\mathrm{C}_{2} \mathrm{mim}\right]^{+}$ & [OTf] $^{-}$ & 1717.4 & -465.92 \\
\hline$\left[\mathrm{C}_{2} \mathrm{mim}\right]^{+}$ & {$[D C A]^{-}$} & 9765.3 & -260.54 \\
\hline$\left[\mathrm{C}_{2} \mathrm{mim}\right]^{+}$ & {$\left[\mathrm{C}_{2} \mathrm{SO}_{4}\right]^{-}$} & 355.51 & 423.56 \\
\hline$\left[\mathrm{C}_{2} \mathrm{mim}\right]^{+}$ & {$\left[\mathrm{C}_{8} \mathrm{SO}_{4}\right]^{-}$} & -423.54 & 2156.2 \\
\hline$\left[\mathrm{C}_{2} \mathrm{mim}\right]^{+}$ & 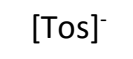 & 35.38 & -13.35 \\
\hline$\left[\mathrm{C}_{3} \mathrm{mim}\right]^{+}$ & {$\left[\mathrm{NTf}_{2}\right]^{-}$} & 67.96 & -111.31 \\
\hline$\left[\mathrm{C}_{4} \mathrm{~m}_{(4)} \mathrm{py}\right]^{+}$ & {$\left[\mathrm{BF}_{4}\right]^{-}$} & -678.30 & 1116.6 \\
\hline$\left[\mathrm{C}_{4} \mathrm{~m}_{(4) \mathrm{py}}\right]^{+}$ & {$\left[\mathrm{NTf}_{2}\right]^{-}$} & 65.77 & -9.79 \\
\hline$\left[\mathrm{C}_{4} \mathrm{~m}_{(3)} \mathrm{py}\right]^{+}$ & {$[\mathrm{DCA}]^{-}$} & 4174.7 & -336.84 \\
\hline$\left[\mathrm{C}_{4} \mathrm{~m}_{(3)} \mathrm{py}\right]^{+}$ & {$\left[\mathrm{NTf}_{2}\right]^{-}$} & 702.97 & -262.88 \\
\hline$\left[\mathrm{C}_{4} \mathrm{~m}_{(3)} \mathrm{py}\right]^{+}$ & {$\left[\mathrm{BF}_{4}\right]^{-}$} & -660.43 & 1990.6 \\
\hline$\left[\mathrm{C}_{4} \mathrm{mim}\right]^{+}$ & {$\left[\mathrm{BF}_{4}\right]^{-}$} & -0.06 & -464.73 \\
\hline$\left[\mathrm{C}_{4} \mathrm{mim}\right]^{+}$ & {$\left[\mathrm{C}_{1} \mathrm{SO}_{4}\right]^{-}$} & 112.45 & -365.32 \\
\hline$\left[\mathrm{C}_{4} \mathrm{mim}\right]^{+}$ & {$\left[\mathrm{NTf}_{2}\right]^{-}$} & 322.36 & -228.33 \\
\hline$\left[\mathrm{C}_{4} \mathrm{mim}\right]^{+}$ & {$\left[\mathrm{PF}_{6}\right]^{-}$} & 1248.42 & -544.06 \\
\hline$\left[\mathrm{C}_{4} \mathrm{mim}\right]^{+}$ & {$[O A c]^{-}$} & 4669.6 & -712.86 \\
\hline$\left[\mathrm{C}_{4} \mathrm{mim}\right]^{+}$ & [OTf] $^{-}$ & -280.50 & -14.04 \\
\hline$\left[\mathrm{C}_{4} \mathrm{mim}\right]^{+}$ & {$[\mathrm{DCA}]^{-}$} & 361.00 & -291.30 \\
\hline$\left[\mathrm{C}_{4} \mathrm{mmim}\right]^{+}$ & {$\left[\mathrm{BF}_{4}\right]^{-}$} & -105.01 & -768.66 \\
\hline
\end{tabular}


Table S3. Continued ...

\begin{tabular}{|c|c|c|c|}
\hline$m$ & $n$ & $\alpha_{m n}$ & $\alpha_{n m}$ \\
\hline$\left[\mathrm{C}_{4} \mathrm{mpyrro}\right]^{+}$ & {$\left[\mathrm{NTf}_{2}\right]^{-}$} & -127.47 & -29.34 \\
\hline 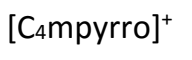 & {$[\mathrm{DCA}]^{-}$} & -208.95 & -53.51 \\
\hline$\left[\mathrm{C}_{4} \mathrm{py}\right]^{+}$ & {$\left[\mathrm{BF}_{4}\right]^{-}$} & -404.47 & 7644.6 \\
\hline$\left[\mathrm{C}_{4} \mathrm{py}\right]^{+}$ & {$\left[\mathrm{NTf}_{2}\right]^{-}$} & 86.82 & 417.64 \\
\hline$\left[\mathrm{C}_{6} \mathrm{mim}\right]^{+}$ & {$\left[\mathrm{BF}_{4}\right]^{-}$} & -155.98 & -414.47 \\
\hline$\left[\mathrm{C}_{6} \mathrm{mim}\right]^{+}$ & {$\left[\mathrm{PF}_{6}\right]^{-}$} & 2912.7 & -584.72 \\
\hline$\left[\mathrm{C}_{6} \mathrm{mim}\right]^{+}$ & [eFAP] $^{-}$ & 439.06 & -274.24 \\
\hline$\left[\mathrm{C}_{6} \mathrm{mim}\right]^{+}$ & {$\left[\mathrm{NTf}_{2}\right]^{-}$} & -251.08 & 415.53 \\
\hline$\left[\mathrm{C}_{8} \mathrm{mim}\right]^{+}$ & {$\left[\mathrm{NTf}_{2}\right]^{-}$} & 80.21 & 36.46 \\
\hline$\left[\mathrm{C}_{8} \mathrm{mim}\right]^{+}$ & {$\left[\mathrm{BF}_{4}\right]^{-}$} & -443.32 & 29.73 \\
\hline$\left[\mathrm{C}_{8} \mathrm{mim}\right]^{+}$ & {$\left[\mathrm{PF}_{6}\right]^{-}$} & -506.07 & 1351.0 \\
\hline$\left[\mathrm{N}_{1114}\right]^{+}$ & {$\left[\mathrm{NTf}_{2}\right]^{-}$} & -3.97 & -9.63 \\
\hline
\end{tabular}


Table S4. Ion VFT parameters used in the first method

\begin{tabular}{|c|c|c|c|c|c|c|c|}
\hline Cation & $A / \mathrm{S} \cdot \mathrm{cm}^{-1}$ & $B / K$ & $T_{0} / \mathrm{K}$ & Anion & $A / \mathrm{s} \cdot \mathrm{cm}^{-1}$ & $B / K$ & $T_{0} / \mathrm{K}$ \\
\hline$\left[\mathrm{C}_{1} \mathrm{mim}\right]^{+}$ & 0.055 & 620.7 & 182.9 & {$\left[\mathrm{BF}_{4}\right]^{-}$} & 1.523 & 451.5 & 182.7 \\
\hline$\left[\mathrm{C}_{2} \mathrm{mim}\right]^{+}$ & 15.672 & 1751.7 & 110.1 & {$\left[\mathrm{C}_{1} \mathrm{SO}_{4}\right]^{-}$} & 0.650 & 278.8 & 186.0 \\
\hline$\left[\mathrm{C}_{3} \mathrm{mim}\right]^{+}$ & 0.044 & 759.2 & 180.4 & {$\left[\mathrm{NTf}_{2}\right]^{-}$} & 7.407 & 300.8 & 170.7 \\
\hline$\left[\mathrm{C}_{4} \mathrm{mim}\right]^{+}$ & 0.314 & 1204.3 & 155.8 & {$\left[\mathrm{PF}_{6}\right]^{-}$} & 0.712 & 351.3 & 215.4 \\
\hline$\left[\mathrm{C}_{6} \mathrm{mim}\right]^{+}$ & 1.047 & 1844.4 & 145.7 & {$[D C A]^{-}$} & 18.019 & 127.9 & 197.9 \\
\hline$\left[\mathrm{C}_{10} \mathrm{mim}\right]^{+}$ & 1.044 & 2095.2 & 142.1 & [Tos $^{-}$ & 0.440 & 333.9 & 232.7 \\
\hline$\left[\mathrm{C}_{4} \mathrm{mmim}\right]^{+}$ & 0.070 & 2134.7 & 161.1 & {$[\mathrm{OAc}]^{-}$} & 1.214 & 444.8 & 244.2 \\
\hline$\left[\mathrm{C}_{4} \mathrm{py}\right]^{+}$ & 15.341 & 1270.9 & 171.6 & [OTf] $^{-}$ & 1.222 & 342.4 & 188.0 \\
\hline$\left[\mathrm{C}_{4} \mathrm{~m}_{(3)} \mathrm{py}\right]^{+}$ & 0.732 & 1102.7 & 174.8 & [eFAP] $]^{-}$ & 3.569 & 125.9 & 183.6 \\
\hline$\left[\mathrm{C}_{4} \mathrm{mpyrro}\right]^{+}$ & 0.080 & 1251.1 & 160.7 & {$\left[\mathrm{C}_{2} \mathrm{SO}_{4}\right]^{-}$} & 4.232 & 141.8 & 174.4 \\
\hline$\left[\mathrm{C}_{8} \mathrm{mim}\right]^{+}$ & 4.582 & 2037.6 & 143.6 & {$\left[\mathrm{C}_{8} \mathrm{SO}_{4}\right]^{-}$} & 0.334 & 843.7 & 184.4 \\
\hline$\left[\mathrm{C}_{4} \mathrm{~m}_{(4)} \mathrm{py}\right]^{+}$ & 7.956 & 1472.1 & 171.2 & & & & \\
\hline$\left[\mathrm{N}_{1114}\right]^{+}$ & 0.190 & 1099.7 & 176.8 & & & & \\
\hline
\end{tabular}


Table S5. Ion VFT parameters used in the second method

\begin{tabular}{|c|c|c|c|c|c|c|c|}
\hline Cation & $A / \mathrm{S} \cdot \mathrm{cm}^{-1}$ & $B / K$ & $T_{0} / \mathrm{K}$ & Anion & $A / \mathrm{S} \cdot \mathrm{cm}^{-1}$ & $B / K$ & $T_{0} / \mathrm{K}$ \\
\hline$\left[\mathrm{C}_{1} \mathrm{mim}\right]^{+}$ & 0.155 & 574.2 & 184.1 & {$\left[\mathrm{BF}_{4}\right]^{-}$} & 0.738 & 464.6 & 187.1 \\
\hline$\left[\mathrm{C}_{2} \mathrm{mim}\right]^{+}$ & 5.303 & 973.9 & 162.3 & {$\left[\mathrm{C}_{1} \mathrm{SO}_{4}\right]^{-}$} & 1.101 & 584.6 & 161.4 \\
\hline$\left[\mathrm{C}_{3} \mathrm{mim}\right]^{+}$ & 0.063 & 601.6 & 192.4 & {$\left[\mathrm{NTf}_{2}\right]^{-}$} & 5.774 & 531.5 & 133.6 \\
\hline$\left[\mathrm{C}_{4} \mathrm{mim}^{+}\right.$ & 0.299 & 911.0 & 173.0 & {$\left[\mathrm{PF}_{6}\right]^{-}$} & 0.656 & 483.2 & 204.5 \\
\hline$\left[\mathrm{C}_{6} \mathrm{mim}\right]^{+}$ & 8.372 & 2407.9 & 115.7 & {$[D C A]^{-}$} & 12.482 & 256.9 & 170.9 \\
\hline$\left[\mathrm{C}_{10} \mathrm{mim}\right]^{+}$ & 5.719 & 2450.8 & 124.8 & [Tos $^{-}$ & 0.367 & 490.5 & 216.6 \\
\hline$\left[\mathrm{C}_{4} \mathrm{mmim}\right]^{+}$ & 0.068 & 1870.7 & 170.0 & {$[\mathrm{OAc}]^{-}$} & 16.747 & 1443.3 & 177.5 \\
\hline$\left[\mathrm{C}_{4} \mathrm{py}\right]^{+}$ & 7.800 & 900.2 & 190.5 & [OTf] $^{-}$ & 1.286 & 631.9 & 150.6 \\
\hline$\left[\mathrm{C}_{4} \mathrm{~m}_{(3)} \mathrm{py}\right]^{+}$ & 0.120 & 482.0 & 218.1 & [eFAP] $]^{-}$ & 3.277 & 244.3 & 177.0 \\
\hline 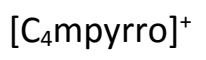 & 0.316 & 1402.7 & 147.9 & {$\left[\mathrm{C}_{2} \mathrm{SO}_{4}\right]^{-}$} & 13.733 & 287.2 & 219.8 \\
\hline$\left[\mathrm{C}_{8} \mathrm{mim}\right]^{+}$ & 17.360 & 2288.9 & 129.1 & {$\left[\mathrm{C}_{8} \mathrm{SO}_{4}\right]^{-}$} & 0.441 & 1234.6 & 157.2 \\
\hline$\left[\mathrm{C}_{4} \mathrm{~m}_{(4)} \mathrm{py}\right]^{+}$ & 1.946 & 921.1 & 197.7 & & & & \\
\hline$\left[\mathrm{N}_{1114}\right]^{+}$ & 0.252 & 910.9 & 187.2 & & & & \\
\hline
\end{tabular}


Table S6. Binary interaction parameters $\alpha_{m n}$ used in the third method

\begin{tabular}{|c|c|c|c|}
\hline$m$ & $n$ & $\alpha_{m n}$ & $\alpha_{n m}$ \\
\hline$\left[\mathrm{C}_{10 \mathrm{mim}}\right]^{+}$ & {$\left[\mathrm{BF}_{4}\right]^{-}$} & 54.19 & -270.90 \\
\hline$\left[\mathrm{C}_{1} \mathrm{mim}\right]^{+}$ & {$\left[\mathrm{NTf}_{2}\right]^{-}$} & -335.08 & 2671.0 \\
\hline$\left[\mathrm{C}_{1} \mathrm{mim}\right]^{+}$ & {$\left[\mathrm{C}_{1} \mathrm{SO}_{4}\right]^{-}$} & -164.36 & -215.21 \\
\hline$\left[\mathrm{C}_{2} \mathrm{mim}\right]^{+}$ & {$\left[\mathrm{BF}_{4}\right]^{-}$} & -229.81 & -232.09 \\
\hline$\left[\mathrm{C}_{2} \mathrm{mim}\right]^{+}$ & {$\left[\mathrm{C}_{1} \mathrm{SO}_{4}\right]^{-}$} & 329.60 & -417.01 \\
\hline$\left[\mathrm{C}_{2} \mathrm{mim}\right]^{+}$ & {$\left[\mathrm{NTf}_{2}\right]^{-}$} & -195.11 & 5216.7 \\
\hline$\left[\mathrm{C}_{2} \mathrm{mim}\right]^{+}$ & {$[\mathrm{OAc}]^{-}$} & -925.37 & 6394.7 \\
\hline$\left[\mathrm{C}_{2} \mathrm{mim}^{+}\right.$ & [OTf] $^{-}$ & 3801.6 & -463.32 \\
\hline$\left[\mathrm{C}_{2} \mathrm{mim}\right]^{+}$ & {$[D C A]^{-}$} & 9765.3 & -119.86 \\
\hline$\left[\mathrm{C}_{2} \mathrm{mim}\right]^{+}$ & {$\left[\mathrm{C}_{2} \mathrm{SO}_{4}\right]^{-}$} & 9.420 & 664.17 \\
\hline$\left[\mathrm{C}_{2} \mathrm{mim}\right]^{+}$ & {$\left[\mathrm{C}_{8} \mathrm{SO}_{4}\right]^{-}$} & -550.64 & 15204.7 \\
\hline$\left[\mathrm{C}_{2} \mathrm{mim}\right]^{+}$ & 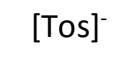 & -199.14 & -12.66 \\
\hline$\left[\mathrm{C}_{3} \mathrm{mim}\right]^{+}$ & {$\left[\mathrm{NTf}_{2}\right]^{-}$} & 65.87 & -78.28 \\
\hline$\left[\mathrm{C}_{4} \mathrm{~m}_{(4)} \mathrm{py}\right]^{+}$ & {$\left[\mathrm{BF}_{4}\right]^{-}$} & -683.25 & 4535.2 \\
\hline$\left[\mathrm{C}_{4} \mathrm{~m}_{(4)} \mathrm{py}\right]^{+}$ & {$\left[\mathrm{NTf}_{2}\right]^{-}$} & 46.06 & -16.07 \\
\hline$\left[\mathrm{C}_{4} \mathrm{~m}_{(3)} \mathrm{py}\right]^{+}$ & {$[\mathrm{DCA}]^{-}$} & 4154.9 & -309.39 \\
\hline$\left[\mathrm{C}_{4} \mathrm{~m}_{(3)} \mathrm{py}\right]^{+}$ & {$\left[\mathrm{NTf}_{2}\right]^{-}$} & 743.26 & -223.16 \\
\hline$\left[\mathrm{C}_{4} \mathrm{~m}_{(3)} \mathrm{py}\right]^{+}$ & {$\left[\mathrm{BF}_{4}\right]^{-}$} & -661.57 & 2876.2 \\
\hline$\left[\mathrm{C}_{4} \mathrm{mim}\right]^{+}$ & {$\left[\mathrm{BF}_{4}\right]^{-}$} & 0.0127 & -509.7 \\
\hline$\left[\mathrm{C}_{4} \mathrm{mim}\right]^{+}$ & {$\left[\mathrm{C}_{1} \mathrm{SO}_{4}\right]^{-}$} & 14.058 & -423.59 \\
\hline$\left[\mathrm{C}_{4} \mathrm{mim}\right]^{+}$ & {$\left[\mathrm{NTf}_{2}\right]^{-}$} & 332.80 & -279.61 \\
\hline$\left[\mathrm{C}_{4} \mathrm{mim}\right]^{+}$ & {$\left[\mathrm{PF}_{6}\right]^{-}$} & 580.02 & -593.66 \\
\hline$\left[\mathrm{C}_{4} \mathrm{mim}\right]^{+}$ & {$[\mathrm{OAc}]^{-}$} & 39026 & -754.45 \\
\hline$\left[\mathrm{C}_{4} \mathrm{mim}\right]^{+}$ & [OTf] $^{-}$ & -278.86 & -117.99 \\
\hline$\left[\mathrm{C}_{4} \mathrm{mim}^{+}\right.$ & {$[\mathrm{DCA}]^{-}$} & 360.74 & -341.09 \\
\hline$\left[\mathrm{C}_{4} \mathrm{mmim}\right]^{+}$ & {$\left[\mathrm{BF}_{4}\right]^{-}$} & -156.79 & -803.83 \\
\hline$\left[\mathrm{C}_{4} \mathrm{mpyrro}\right]^{+}$ & {$\left[\mathrm{NTf}_{2}\right]^{-}$} & -242.49 & -73.50 \\
\hline
\end{tabular}


Table S6. Continued ...

\begin{tabular}{|c|c|c|c|}
\hline$m$ & $n$ & $\alpha_{m n}$ & $\alpha_{n m}$ \\
\hline$\left[\mathrm{C}_{4} \mathrm{mpyrro}^{+}\right.$ & {$[D C A]^{-}$} & -428.18 & -291.61 \\
\hline$\left[\mathrm{C}_{4} \mathrm{py}\right]^{+}$ & {$\left[\mathrm{BF}_{4}\right]^{-}$} & -441.1 & 18057 \\
\hline$\left[\mathrm{C}_{4} \mathrm{py}\right]^{+}$ & {$\left[\mathrm{NTf}_{2}\right]^{-}$} & 64.51 & 240.96 \\
\hline$\left[\mathrm{C}_{6} \mathrm{mim}\right]^{+}$ & {$\left[\mathrm{BF}_{4}\right]^{-}$} & -64.98 & -161.37 \\
\hline$\left[\mathrm{C}_{6} \mathrm{mim}^{+}\right.$ & {$\left[\mathrm{PF}_{6}\right]^{-}$} & 1399.7 & -428.91 \\
\hline$\left[\mathrm{C}_{6} \mathrm{mim}\right]^{+}$ & [eFAP] $^{-}$ & 712.20 & -124.31 \\
\hline$\left[\mathrm{C}_{6} \mathrm{mim}\right]^{+}$ & {$\left[\mathrm{NTf}_{2}\right]^{-}$} & -228.61 & 1279.2 \\
\hline$\left[\mathrm{C}_{8} \mathrm{mim}\right]^{+}$ & {$\left[\mathrm{NTf}_{2}\right]^{-}$} & 65.22 & -81.20 \\
\hline$\left[\mathrm{C}_{8} \mathrm{mim}\right]^{+}$ & {$\left[\mathrm{BF}_{4}\right]^{-}$} & -473.02 & 39.35 \\
\hline$\left[\mathrm{C}_{8} \mathrm{mim}\right]^{+}$ & {$\left[\mathrm{PF}_{6}\right]^{-}$} & -590.31 & 17735 \\
\hline$\left[\mathrm{N}_{1114}\right]^{+}$ & {$\left[\mathrm{NTf}_{2}\right]^{-}$} & -0.282 & 27.65 \\
\hline
\end{tabular}


Table S7. Ion VFT parameters used in the third method

\begin{tabular}{|c|c|c|c|c|c|c|c|}
\hline Cation & $A / \mathrm{S} \cdot \mathrm{cm}^{-1}$ & $B / K$ & $T_{0} / \mathrm{K}$ & Anion & $A / \mathrm{S} \cdot \mathrm{cm}^{-1}$ & $B / K$ & $T_{0} / \mathrm{K}$ \\
\hline$\left[\mathrm{C}_{1} \mathrm{mim}\right]^{+}$ & 0.137 & 501.0 & 188.1 & {$\left[\mathrm{BF}_{4}\right]^{-}$} & 1.340 & 577.7 & 170.0 \\
\hline$\left[\mathrm{C}_{2} \mathrm{mim}\right]^{+}$ & 0.428 & 612.6 & 154.4 & {$\left[\mathrm{C}_{1} \mathrm{SO}_{4}\right]^{-}$} & 3.932 & 1095.8 & 137.2 \\
\hline$\left[\mathrm{C}_{3} \mathrm{mim}\right]^{+}$ & 0.033 & 405.3 & 218.8 & {$\left[\mathrm{NTf}_{2}\right]^{-}$} & 1.963 & 253.7 & 156.7 \\
\hline$\left[\mathrm{C}_{4} \mathrm{mim}\right]^{+}$ & 0.136 & 868.8 & 181.1 & {$\left[\mathrm{PF}_{6}\right]^{-}$} & 3.347 & 976.4 & 161.9 \\
\hline$\left[\mathrm{C}_{6} \mathrm{mim}\right]^{+}$ & 2.210 & 1143.2 & 174.6 & {$[D C A]^{-}$} & 19.748 & 387.2 & 105.0 \\
\hline$\left[\mathrm{C}_{10} \mathrm{mim}\right]^{+}$ & 0.723 & 1366.6 & 171.2 & 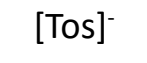 & 0.606 & 828.2 & 205.0 \\
\hline$\left[\mathrm{C}_{4} \mathrm{mmim}\right]^{+}$ & 0.020 & 1815.6 & 172.6 & {$[\mathrm{OAc}]^{-}$} & 0.421 & 731.6 & 206.3 \\
\hline$\left[\mathrm{C}_{4} \mathrm{py}\right]^{+}$ & 4.604 & 870.6 & 193.7 & [OTf] $^{-}$ & 1.295 & 689.0 & 133.1 \\
\hline$\left[\mathrm{C}_{4} \mathrm{~m}_{(3)} \mathrm{py}\right]^{+}$ & 0.554 & 746.9 & 202.4 & [eFAP] $]^{-}$ & 3.871 & 168.6 & 204.9 \\
\hline 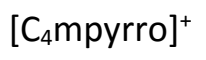 & 0.108 & 1576.9 & 147.4 & {$\left[\mathrm{C}_{2} \mathrm{SO}_{4}\right]^{-}$} & 13.815 & 365.6 & 228.2 \\
\hline$\left[\mathrm{C}_{8} \mathrm{mim}\right]^{+}$ & 0.400 & 1225.3 & 177.0 & {$\left[\mathrm{C}_{8} \mathrm{SO}_{4}\right]^{-}$} & 0.814 & 1653.2 & 158.9 \\
\hline$\left[\mathrm{C}_{4} \mathrm{~m}_{(4)} \mathrm{py}\right]^{+}$ & 0.932 & 806.8 & 205.2 & & & & \\
\hline$\left[\mathrm{N}_{1114}\right]^{+}$ & 0.944 & 1130.4 & 179.6 & & & & \\
\hline
\end{tabular}

